\title{
THE POLITICAL GEOGRAPHY OF LEGAL INTEGRATION
}

\section{Visualizing Institutional Change in the European Union}

\author{
By R. DANIEL KELEMEN and TOMMASO PAVONE*
}

\section{INTRODUCTION}

$\mathrm{T}$ $1 \mathrm{HE}$ European Union is an exemplary case of political development through law. Advancing the rule of law is not just a normative aspiration for the EU; it is the EU's primary mode of governance. Given its limited fiscal resources and the weakness of its administrative apparatus, the EU relies heavily on a judicialized mode of governance, enlisting private litigants to pursue its policy objectives and incorporating national courts into a pan-European judicial order. ${ }^{1}$ In this light, while the EU is not a state in the traditional, coercive sense, ${ }^{2}$ it can be conceptualized as a modern version of what medievalist historian Joseph Strayer called a "law-state" - a political order constructed principally through the progressive expansion of its judicial institutions. ${ }^{3}$

Importantly, the EU is not constructing its law-state on a tabula rasa, but on an institutional terrain populated by preexisting legal orders. In this respect, the EU's experience has much in common with episodes of state building from late-medieval and early-modern Europe ${ }^{4}$ to the nineteenth-century United States and other coming-together federa-

\footnotetext{
*We would like to thank participants at the 2016 APSA meeting, the 2017 EUSA conference, and three anonymous reviewers for their constructive feedback on earlier versions of this article. All remaining errors are our own. The order of author names is alphabetical; both equally contributed to the manuscript.

Replication code for this article is available at Kelemen and Pavone 2018a.

${ }^{1}$ Kelemen 2011; Kelemen 2016.

${ }^{2}$ Weber 1921 defined the state as "a human community that (successfully) claims the monopoly of the legitimate use of physical force within a given territory."

${ }^{3}$ Strayer 1970, 61. See also Fukuyama 2012, 271, and Berman 1983, 406, on the concept of states built primarily through subsuming preexisting local legal orders into a new, overarching legal order.

${ }^{4}$ Strayer 1970; Fukuyama 2012; Berman 1983; Boucoyannis 2005.
}

World Politics, 70, no. 3 (July 2018), 358-97

Copyright (C) 2018 Trustees of Princeton University doi: 10.1017/S0043887118000011 
tions, ${ }^{5}$ or with the development of international regimes modeled on the EU like the Andean Community. ${ }^{6}$ In all these multilevel, multijurisdictional settings, those who would construct new, overarching judicial institutions work to reform and incorporate existing judicial institutions in the new legal order. These processes of institutional change occur incrementally through mechanisms identified by historical institutionalists, namely layering and conversion. ${ }^{7} \mathrm{New}$ legal rules are layered atop existing ones, and at the same time those existing institutions are gradually converted to serve new purposes.

Building on this historical institutionalist perspective, this article explores how the EU's legal order has developed and expanded over space and time. Over the past six decades, the architects of the EU legal order have layered new supranational institutions atop existing national legal orders while seeking to convert national judiciaries into EU courts. Specifically, we analyze how this process has been affected by its interaction with the preexisting judicial orders of its member states. In so doing, we show how these institutional developments not only have a temporal dimension that can be uncovered via time-series analysis, process tracing, and comparative historical analysis, ${ }^{8}$ but also have a spatial structure that can be visualized and analyzed through mapping. ${ }^{9}$ By theorizing and empirically evaluating the political geography of European legal integration, our approach demonstrates how scholars can literally "see" historical institutionalism at work.

Indeed, although the existing literature emphasizes that the EU judicial order is a key driver of European integration, it is less attentive to the political geography that underlies this process of institutional change. This spatiotemporal dimension matters because for the EU, as for any state or polity, the capacity to govern in practice depends on the geographical extent and temporal consistency with which it exercises authority across its territory. As Michael Mann puts it, the strength of a state depends on its infrastructural power: its institutional capability to exercise authority and implement policy throughout the territory it seeks to govern. ${ }^{10}$ For a political order like the EU that seeks to rule principally through law, spatiotemporal measures of the reach of the

\footnotetext{
${ }^{5}$ Skowronek 1982; Crowe 2012.

${ }^{6}$ Alter and Helfer 2017.

${ }^{7}$ Streeck and Thelen 2005, 22-30; Mahoney and Thelen 2010, 16-22.

${ }^{8}$ Mahoney and Rueschemeyer 2003; Bennett and Checkel 2014.

${ }^{9}$ Frymer 2017.

${ }^{10}$ Mann 1984.
} 
regime's judicial authority arguably provide the best gauge of its infrastructural power. ${ }^{11}$

In this vein, a powerful indicator of the reach of the EU's judicial authority is an institutional mechanism known as the preliminary reference procedure. ${ }^{12}$ The procedure empowers any national court to refer a question on the interpretation of EU law to the European Court of Justice (ECJ) in Luxembourg, ${ }^{13}$ thereby serving as a transmission belt linking domestic courts with the ECJ. Although formally all national judges are treaty-bound to respect the supremacy of EU law and are encouraged to solicit the interpretive authority of the ECJ, use of the preliminary reference procedure signals where these European rules are actually being translated into concrete practice on the ground. When a national judge refers a lawsuit hinging on the application of EU law to the ECJ, that judge collaborates with the European Court to enforce EU law over conflicting national or local law, empowering local litigants to have their case heard by the ECJ in Luxembourg. Therefore, preliminary reference activity indicates where litigants' EU legal rights are most likely to be judicially enforced, and where evidence of local noncompliance is most likely to percolate upward to the ECJ, enabling it to "see like a state" as it exercises its authority. ${ }^{14}$ In historical institutionalist terms, preliminary references signal where the layering of EU law atop national law has successfully converted national judges into EU judges.

But what is known about the penetration of the European judicial order via the reference procedure across the territory of EU member states over the past six decades? Pioneering work by several scholars ${ }^{15}$ explains how a mutually empowering relationship between the ECJ in Luxembourg and low-level referring judges in the six founding-member states sparked the early development of the EU's supranational legal order. More recent studies examine cross-national variation in the rate of references from national courts and across policy areas, ${ }^{16}$ and conduct

\footnotetext{
${ }^{11}$ Infrastructural power is a thick concept that can be measured by multiple indicators (Soifer 2012), and the appropriate indicators (ranging from the proliferation of bureaucratic offices to tax collections to the maintenance of military garrisons to the presence of courts) will vary depending on the character of the polity in question.

${ }^{12}$ Under Article 267 of the Treaty on the Functioning of the European Union (TFEU).

${ }^{13}$ Although all national courts can refer cases to the ECJ, formally, only courts of last instance are obligated to refer questions on the interpretation of EU law. In practice, however, domestic supreme courts retain substantial discretion, for they can avoid referring a case to the ECJ by proclaiming that no interpretive doubt exists (under the ECJ's acte clair doctrine). See Case 283/81, Srl CILFIT and Lanificio di Gavardo SpA v. Ministry of Health, [1982], ECR 3417.

${ }^{14}$ Scott 1998.

${ }^{15}$ Weiler 1991; Burley and Mattli 1993; Alter 2001.

${ }^{16}$ Wind 2010; Stone Sweet 2004; Chalmers and Chaves 2012.
} 
careful impact studies of how the ECJ judgments these references generate are applied. ${ }^{17}$

Yet little is known about how the incremental layering of EU law upon national law and the conversion of national judiciaries into courts of the EU legal order have been "structured across space and time," 18 and we lack a theory that may explain these developments. As a result, fundamental questions remain unanswered: How has the spatial reach of EU law evolved over time within and across member states? What explains these varied spatiotemporal patterns, and how can the answer contribute novel insights to the study of institutional change?

To answer these questions, we extend and reformulate existing theories of European political development into a spatiotemporal theory of legal integration. Generally, arguments rooted in neofunctionalism and related institutionalization perspectives should expect EU law litigation to spread spatially through a bottom-up "expansive, self-sustaining process" of mutual empowerment between low-level national courts, legal professionals, and the ECJ. ${ }^{19}$ Conversely, perspectives derived from intergovernmentalist theories emphasizing the enduring power of national institutions may expect national governments and other apex state institutions that share an interest in preserving national autonomy - such as supreme courts - to shape the spread of EU law by promoting normative consensus for or against European legal integration from the top down. ${ }^{20}$

We propose an argument that melds aspects of both perspectives, building on historical institutionalist studies of how national institutions channel-even if they do not strictly control - the forces associated with European integration. ${ }^{21} \mathrm{We}$ argue that while growing structural demand for EU law and the efforts of Europeanist change agents have spread preliminary reference activity over time within EU member states, its spatiotemporal pattern continues to be shaped by national institutions-particularly domestic judiciaries. ${ }^{22}$ How domestic judicial orders are structured determines the degree to which national apex

\footnotetext{
${ }^{17}$ Treib 2008; Martinsen 2015.

${ }^{18}$ Hall 2016.

${ }^{19}$ Stone Sweet 2010, 16-22; Jupille and Caporaso 2009.

${ }^{20}$ Garrett 1992; Carrubba, Gabel, and Hankla 2008; Parsons 2003.

${ }^{21}$ Lindseth 2010; Fioretos 2011.

${ }^{22}$ We use the term "diffusion" colloquially and interchangeably with "spread," rather than in the stricter sense implying a causal mechanism in which the introduction of a practice at time $t$ in location A increases the likelihood of the adoption of the same practice in proximate locations at time $t+n$. Though we analyze issue-specific spatial clustering of EU law litigation, our analysis examines how entrenched domestic institutions shape the structure of the EU legal order's reach within the territory of member states, rather than focusing on interjurisdictional spillovers.
} 
institutions like supreme courts and national governments can control the use of the reference procedure and thus the spread of EU law. When state judiciaries are decentralized, the spread of EU law will be more incrementally driven from the bottom up by autonomous lower courts, exhibiting greater subnational variation even as the number of cases referred to the ECJ steadily increases over time. When state judiciaries are centralized, the penetration of EU law will be more temporally volatile and driven from the top down by supreme courts, which can leverage their authority to uniformly dissuade or promote preliminary references from lower courts throughout the state's territory.

To assess these claims, we deploy tools of geospatial analysis (using geographic information systems [GIS] technology) that while common in other fields of study ${ }^{23}$ are altogether novel in EU studies, ${ }^{24}$ and have been applied only rarely in the study of law and courts more generally. ${ }^{25}$ We begin in Section II by elaborating our argument and deriving a number of empirically testable hypotheses. In Sections III and IV we introduce our data, justify our case selection, and assess the validity of these hypotheses across three of the six founding members of the EU: France (a unitary state with a centralized, hierarchical judiciary); Italy (a weak unitary state with a centralized, hierarchical judiciary); and Germany (a federal state with a decentralized judiciary). Finally, in Section V we conclude by highlighting how this article informs the study of institutional change. Indeed, because the general question we explore is how a new, overarching system of law spreads as its proponents run into a set of preexisting, well-institutionalized legal orders, our arguments and findings should also be of interest to scholars studying the role of law in American political development, ${ }^{26}$ the emergence of transnational legal orders, ${ }^{27}$ and processes of state formation through "coming-together federalism." ${ }^{28}$

\section{Theory: Domestic Judiciaries and the Political Geography of EU LaW Litigation}

Lord Denning, the renowned English judge, famously characterized EU law as an incoming tide, saying, "[I]t flows into the estuaries and up

\footnotetext{
${ }^{23}$ Such geospatial approaches are increasingly used in subfields of political science, such as American politics (Cho and Gimpel 2012), comparative politics (Franzese and Hays 2008; Stasavage 2010; Cammett and Issar 2010), and international relations (Gleditsch and Ward 2006), but have been seldom applied to the study of law and courts and by historical institutionalist scholars.

${ }^{24}$ See Kelemen and Pavone 2016 for a plausibility probe of this approach.

${ }^{25}$ See Ingram 2016 for an exception.

${ }^{26}$ Orren and Skowronek 2004; Frymer 2008.

${ }^{27}$ Halliday and Shaffer 2015.

${ }^{28}$ Stepan 1999.
} 
the rivers. It cannot be held back." ${ }^{29}$ Most scholars of the EU legal system share this view. That is, a rich body of research finds that European legal integration has been an expansive process, leading to dramatic growth over time in the range of policy fields addressed by EU law, the groups of actors with specialized knowledge of EU law, and the judicial enforcement of EU law via the preliminary reference procedure.

This research generally stresses both the effects of structural variables and the impact of institutional change agents. On the structural side, demand-centric, cross-national analyses have uncovered a positive correlation between preliminary reference activity and trade, GDP per capita, and population levels. ${ }^{30}$ Importantly, the only statistical analysis to date of the impact of structural variables on EU law litigation at the subnational level uncovered that population levels are by far the strongest predictor of preliminary references. ${ }^{31}$ The underlying logic is that lawsuits gravitate to where people live and disputes amongst private parties or between private parties and the state are more likely to arise. In this view, the claiming of international rules in domestic legal proceedings is a process centered in urban areas and more rare in rural areas.

On the institutional and agentic side, scholars have traced how "the activities of market actors, lobbyists, legislators, litigators, and judges had become connected" in ways that "constituted a self-reinforcing system" leading to the steady expansion of the EU legal order. ${ }^{32}$ Likewise, a group of socio-legal scholars and historians has demonstrated that a distinctive cohort of actors (including large law firms, specialist "Eurolawyers," academics, judges, and NGOs) possessing specialist knowledge of EU law together constitute a "European legal field" that has actively promoted the spread of EU law litigation. ${ }^{33}$

Although the causal mechanisms stressed by the existing literature differ, the observable implication of these studies is that European law has incrementally begun to embed itself within domestic legal orders, largely via the spreading use of the preliminary reference procedure. In contrast, we argue that even when structural demand and institutional change agents are taken into account, the spatial and temporal pattern of EU law litigation will continue to be shaped by the structures of domestic judiciaries and the states within which they are embedded.

\footnotetext{
${ }^{29}$ See HP Bulmer Ltd. v. J. Bollinger SA [1974] Ch. 401 at 418.

${ }^{30}$ Stone Sweet and Brunell 1998; Tridimas and Tridimas 2004; Vink, Claes, and Arnold 2009.

${ }^{31}$ Kelemen and Pavone 2016.

${ }^{32}$ Stone Sweet 2010, 17.

${ }^{33}$ Vauchez and de Witte 2013.
} 


\section{The Spread of Preliminary Reference Activity across Time AND SPACE}

First, consider decentralized judiciaries, such as Germany's, comprising relatively autonomous, functionally differentiated, and specialized subunits. The autonomy of these regionally organized judiciaries, in which judges are locally recruited, appointed, promoted, salaried, and disciplined, means that lower and mid-level judicial actors have the discretion necessary to innovate - an element that has been stressed as fundamental by the scholarship on bureaucratic innovativeness. ${ }^{34}$ The local ties of judges in such systems also increases the likelihood that some will perceive complementarities ${ }^{35}$ between EU law and local disputes, and thereby choose to send references to the ECJ. Yet, while local control and flattened relations of authority facilitate policy innovation, they also inhibit the rapid and uniform spread of innovations across the judicial system. That is, the very autonomy and specialization that render an innovation possible can also compartmentalize its adoption. And the lack of streamlined, vertical channels of authority limits the ability of central actors to quickly monopolize or mandate adoption. ${ }^{36}$ The observable implication is that in decentralized judicial orders, use of the reference procedure is unlikely to be uniform or to be speedily monopolized by judges at the apex of the domestic judicial hierarchy. Rather, its uptake should proceed gradually, unevenly, and from the bottom up, with reference rates becoming intense in some regions and remaining scarcer in others.

These dynamics should play out very differently in centralized and hierarchical judiciaries — such as that of France - in which judges are recruited, appointed, salaried, and disciplined by national institutions. We theorize that centralized and hierarchical judiciaries are likely to limit the autonomy of inferior judges and to temper functional differentiation and specialization. Because innovative decision-making in centralized organizations is conditioned by the approval of the top echelons of the authority structure, hierarchical judiciaries are likely to resist a culture of autonomy and local innovativeness among their lower ranks. ${ }^{37}$ Furthermore, the greater integration of the judicial subunits within the hierarchy, combined with the central role played by powerful superior courts, limits functional specialization and instead incentivizes institutional isomorphism and homogeneity of practices. ${ }^{38}$

${ }^{34}$ Teece 1996, 197-205.

${ }^{35}$ Teece 1996; Strang and Soule 1998, 270.

${ }^{36}$ Strang and Meyer 1993; Robertson and Langlois 1995; Teece 1996; Strang and Soule 1998.

${ }^{37}$ Teece 1996, 197-200, 211.

${ }^{38}$ Powell and DiMaggio 2012. 
In this type of centralized, hierarchical context, we are less likely to observe either significant bottom up-driven innovation or substantial cross-regional differences in judicial practices. If use of the reference procedure diffuses, it is likely to do so after the upper tiers of the judiciary have signaled their approval. Further, a novel practice like the use of the reference procedure can be more rapidly adopted throughout a centralized judiciary, ${ }^{39}$ because centralized institutions facilitate "much broader diffusion processes, since their effects do not vary across sites or adopters." ${ }^{" 0}$ But while diffusion may proceed more rapidly, it may also be reversed or contained. If high courts signal to their inferiors that they should limit references to the ECJ-as a result of political pressure against the practice or a desire to assert greater control over the dialogue with the ECJ-then we would expect the geographic spread of the practice to slow or reverse. These considerations lead us to two closely related hypotheses:

-H1a. The more hierarchically centralized a state's judiciary, the greater the temporal variability in spatial coverage of EU law litigation via the preliminary reference procedure.

-H1b. The more decentralized a state's judiciary, the greater the interregional variation in levels of EU law litigation via the preliminary reference procedure.

\section{The Spatial Clustering of Preliminary Reference Activity}

A political geography perspective also sheds light on patterns of spatial clustering. A rich literature in economic geography demonstrates that agglomeration effects driven by local knowledge spillovers can help generate path-dependent local clusters specializing in particular industries. ${ }^{41}$ Similarly, because spatial proximity facilitates the localized diffusion of knowledge and judicial practices regarding specific fields of law, one should expect issue-specific hot spots of judicialized enforcement of EU law to emerge in member states. The distribution of such hot spots, however, may vary depending on domestic institutional structures.

In particular, hot spots of EU law litigation may emerge within member states in locations where a subset of EU rules is particularly relevant to the local socioeconomic context. For instance, hot spots of trade-related litigation-particularly rules governing the free movement of goods and services - may emerge near ports where maritime

\footnotetext{
${ }^{39}$ Robertson and Langlois 1995, 556.

${ }^{40}$ Strang and Meyer 1993, 490-94.

${ }^{41}$ Krugman 1991; Audretsch 1998; Feldman 1999.
} 
trade activity is concentrated, whereas hot spots of litigation relating to mergers and acquisitions may emerge near a country's financial hubs. This would reflect the common exposure of such locations to social or economic activities regulated in part by EU rules. Further, superior courts (of appeal or last instance) specializing in EU law may generate knowledge spillovers and other agglomeration effects to spatially proximate areas. For instance, a city that is home to a high court that frequently refers cases to the ECJ concerning a specific issue area may attract a cluster of specialized EU legal practitioners to locate in its proximity, and these practitioners may then apply their legal expertise before other (lower) courts in the area.

Although we expect that issue-specific spatial clustering would emerge in any member state, it should be more pronounced in countries with decentralized judiciaries, since their courts possess the competence and autonomy necessary to respond to local demands and to develop location-specific practices regardless of whether they are promoted by their superior counterparts. Meanwhile, in states with more hierarchically centralized judiciaries, the tendency toward issue-specific spatial clusters should be tempered by the standardization of judicial practices throughout the territory. This causal reasoning leads to two closely related hypotheses:

$-\mathrm{H} 2 \mathrm{a}$. The use of the preliminary reference procedure will exhibit issue-specific spatial clustering.

- H2b. The more decentralized a state's judiciary, the greater the extent to which use of the preliminary reference procedure will exhibit issuespecific spatial clustering.

\section{Case Selection and Data}

\section{Case Selection and Conceptualizing Judicial (De)CENTRALIZATION}

To assess how the spatial diffusion of the EU's preliminary reference procedure has evolved over time and is shaped by the organization of domestic judicial systems, we focus our analysis on France, Italy, and (West) Germany. The selection of these three cases is desirable for several reasons. First, France, Italy, and Germany were part of the original six EEC member states. Because they were exposed to the establishment of the European legal order at the same time, we can ensure comparability, and because EU legal integration spans the five decades since the founding of the system, we can probe long-term, subnational trends. By contrast, states that joined the EU at a later date may be less comparable 
and susceptible to "newcomer effects." This is the reason we focus on preliminary reference activity from courts in West Germany and exclude their East German counterparts, which joined the EU legal order decades later. Second, French, Italian, and German courts have been the most prolific referrers of cases to the ECJ, which means that by analyzing the subnational penetration of the EU legal order across these cases we are accounting for a large share of the total reference activity across the EU. Third, the structure of French, Italian, and German state institutions varies in ways that enable us to assess our theoretical claims.

Specifically, France is a unitary state that boasts a centralized, hierarchical judiciary; Italy is a weaker unitary state with a centralized, hierarchical judiciary; and Germany is a federal state with a decentralized judiciary and flatter relations of authority. Of course, the relative centralization or decentralization of state institutions is a multidimensional concept that can be measured with a variety of indicators. ${ }^{42} \mathrm{We}$ focus primarily on two. First, we draw upon the new Regional Authority Index (RAI), a composite measure of ten dimensions of state decentralization, ${ }^{43}$ which captures the self-rule capacity of subnational jurisdictions, as well as their ability for shared rule or to influence national policy-making. By this measure, where a lower RAI score indicates greater centralization of authority, France is more centralized (with an average RAI score of 13.6) than Italy (17.4), and both are much more centralized than Germany (34.7).

Although the degree to which the state is centralized or decentralized is relevant to our argument-as any judiciary is embedded within a broader political context that influences its operation-we are more precisely interested in the organization of national judiciaries. For this reason we also rely on a new measure of judicial decentralization ${ }^{44}$ that aims to be a judiciary-specific analogue to the RAI: the Judicial Regional Authority Index (JRAI). The JRAI is divided into multiple dimensions, of which seven are of particular interest here. Specifically, Table 1 displays the organization of the French, Italian, and German judiciaries based on the composite RAI score and the relevant dimensions of the JRAI. Clearly, although the French judiciary is embedded within a more unitary state structure than is the Italian judiciary (according to their RAI scores), both are equally centralized. Conversely, the German judiciary

\footnotetext{
${ }^{42}$ Treisman 2002; Ziblatt 2007; Hooghe et al. 2016.

${ }^{43}$ See Hooghe et al. 2016. These dimensions are institutional depth, policy scope, fiscal autonomy, borrowing autonomy, representation, law-making, executive control, fiscal control, borrowing control, and constitutional reform.

${ }^{44}$ Vallbe 2014.
} 


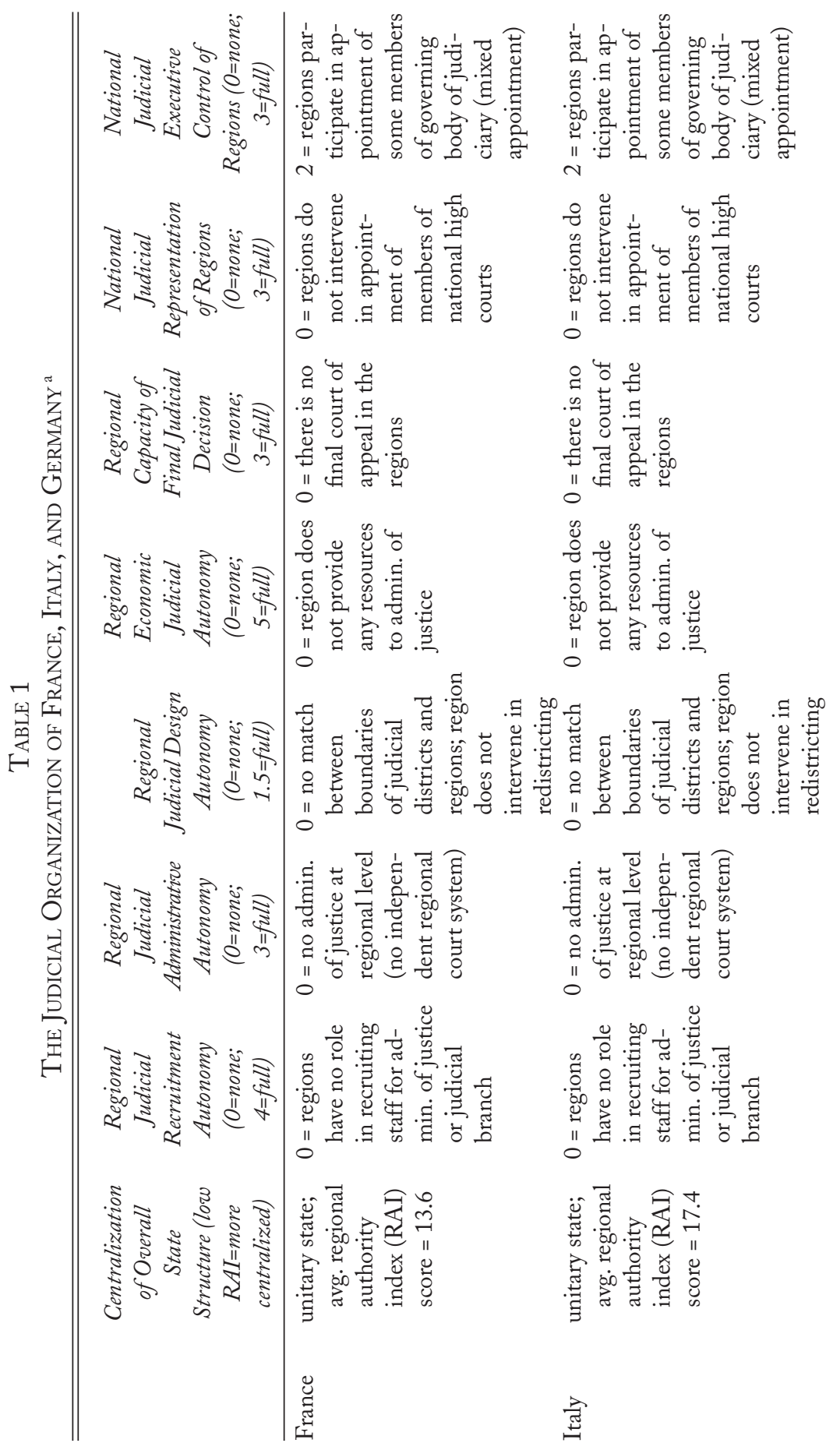




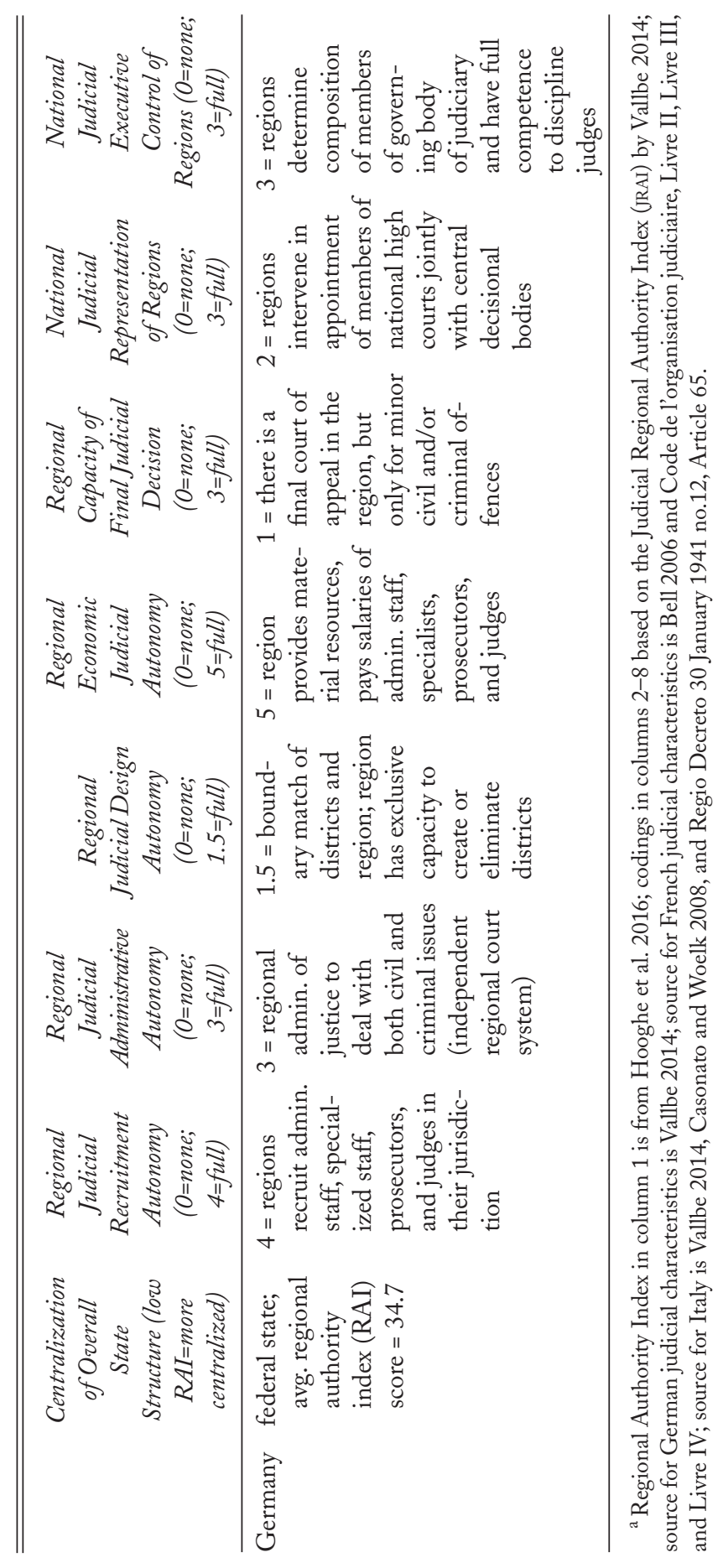


is not only embedded within a federal state, but is also very decentralized. As John Bell underscores, "the [German] court system is predominantly a Land [regional] matter and most judges are Land civil servants. Rules on legal education, appointment, and promotion are specific to a particular Land." ${ }^{45}$ By contrast, recruitment, appointment, and promotion in France and Italy are centralized in their respective judicial high councils; court funding and judicial salaries are determined by their ministries of justice; and subnational jurisdictions play no direct fiscal, disciplinary, or administrative role.

One benefit of focusing on the relative centralization of the judiciary is that court systems have been resistant to decentralizing reforms. For example, whereas the Italian regions have been delegated greater authority over time (causing Italy's RAI score to grow from 10 to 27.3 between 1950 and 2010), its JRAI score has remained stable during the same period (ranging between 0.04 and 0.06). But because the political dynamics within national states are driven by interactions between member-state bureaucracies-including between the judicial branch and the political branches-focusing exclusively on the JRAI score would lead to an inaccurate assessment of centralization for our purposes. For example, in states with centralized political institutions, national parliaments may more effectively wield their power to influence the decisions of apex courts. Since we treat a national judiciary as a bureaucratic organization embedded within a broader political order, we weigh the RAI and the JRAI equally. Hence, our expectation is that centralizing dynamics should be greatest in the French judiciary and least in Germany, with Italy falling between the two.

DATA

Our empirical analysis is based on an original data set containing the city of origin (geolocation) of every reference for a preliminary ruling submitted by a French, Italian, or (West) German court to the ECJ from 1964 to 2013. This amounts to 769 references from France, 1,223 references from Italy, and 1,722 from Germany (total $n=3,714$ ). To employ spatial statistics for parts of our analysis, it is necessary to aggregate these data into territorial units. For precision, we choose to aggregate at the lowest common territorial unit of organization across the three countries: the NUTS3 (nomenclature of territorial units for statistics) level (the French department, Italian province, and German

${ }^{45}$ Bell 2006, 110. 
district). ${ }^{46}$ As a control for demographic demand for some of our analyses, we match the reference data at the NUTS3 level with official population data obtained from the three countries' respective state statistical agencies. Although a number of structural or socioeconomic factors have been used to predict preliminary reference activity, some scholars $^{47}$ have found that population levels are the most temporally and geographically consistent correlates of EU law litigation, which bolsters our confidence in population serving as a strong proxy for structural demand for the judicial enforcement of EU law. Because we are only able to obtain these data since 1975 in France and Germany and since 1982 in Italy, the temporal frame of those analyses that use population as a control is necessarily restricted, but still spans over three decades.

\section{RESULTS}

\section{The Diffusion of Preliminary Reference Activity across Time AND Space}

It is well known among scholars of EU law that the total number of references sent from national courts to the ECJ has increased dramatically over the past six decades. But little is known about how the spatial distribution of these references within member states has evolved over time. To explore this, we use GIS and spatial statistics to map and analyze the spatial diffusion of EU law litigation. Before explicitly testing our causal hypotheses, we first present an introductory set of maps to illustrate the diffusion of the preliminary reference procedure. We show that this form of EU judicial enforcement is indeed spreading over time within the territory of all three member states. We also present econometric evidence suggesting that leading explanations based on structural demand and the role of institutional change agents leave some patterns of diffusion unexplained.

First, Figure 1 maps preliminary references originating from France, Italy, and Germany from 1964 to 2013, showing the total number of references by decade based on their city of origin (with larger circles indicating more references originated from that city within a given decade). The figure demonstrates that the use of the reference procedure has grown not just in quantitative terms (consistent with existing research), but has expanded spatially as well. That is, not only is EU law

\footnotetext{
${ }^{46}$ Eurostat uses NUTS designations to divide up the territory of the EU, collect regional statistics, and render these statistics comparable.

${ }^{47}$ For example, Vink, Claes, and Arnold 2009.
} 

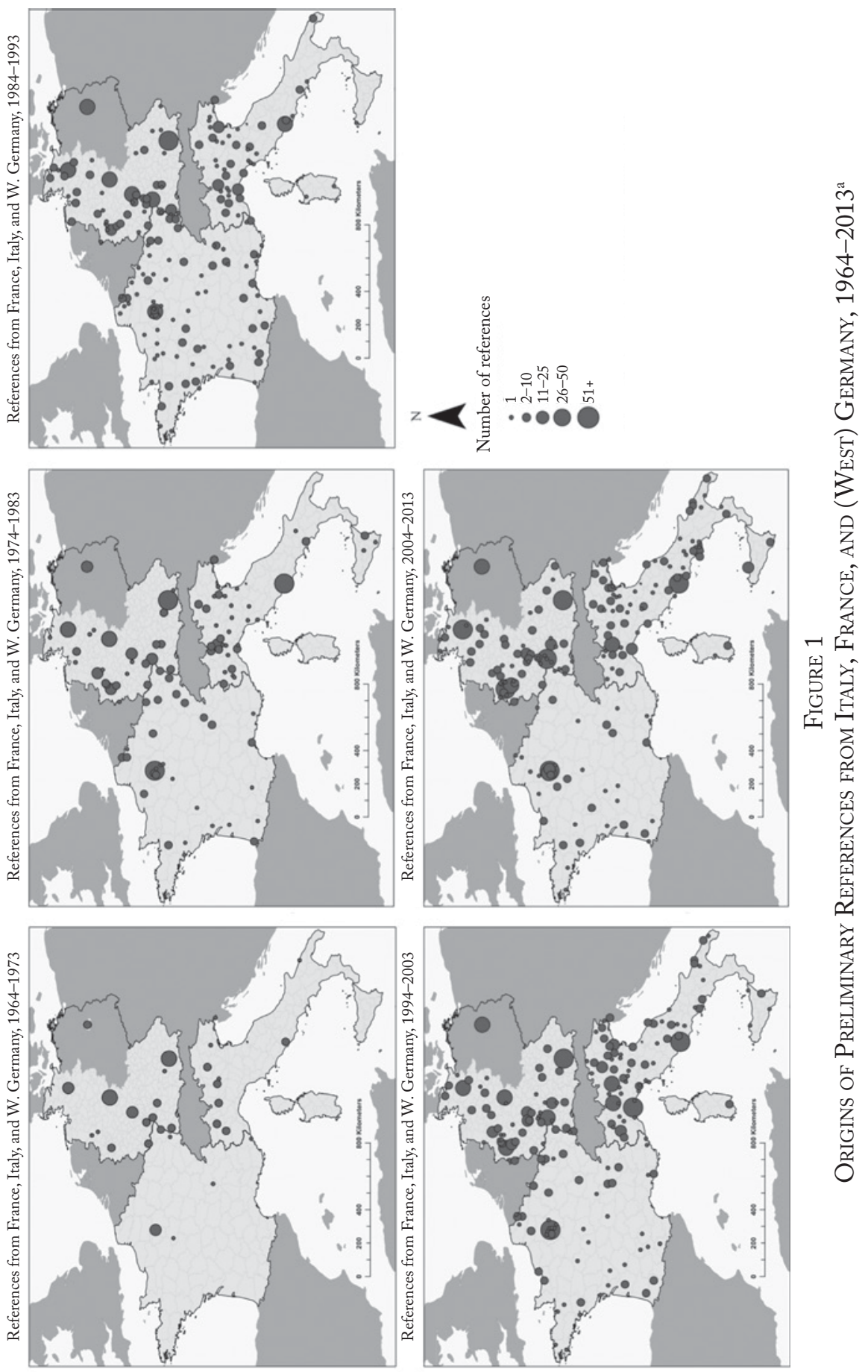
litigation via the reference procedure on the rise, but national courts participating in the system of EU legal enforcement by referring cases to the ECJ are also distributed over a greater proportion of each state's territory. ${ }^{48}$

Beyond descriptive statistics, our empirical premise is that leading explanations for EU law litigation focused on structural demand and the activities of legal pioneers do not fully explain spatiotemporal patterns in preliminary reference activity. To establish the plausibility of this premise, we construct an original data set that contains the number of yearly preliminary references within each NUTS3 region-roughly the lowest level of administrative organization recognized by Eurostat. We then link each NUTS3 region-year observation with a proxy measure for structural demand and for the mobilizing role of institutional change agents.

As an indicator of structural demand for EU law litigation, we follow previous scholars by relying on logged population..$^{49}$ There are two primary reasons for this choice. First, existing research has found that population levels are a significant predictor of preliminary reference activity, and that accounting for population washes out the effects of other covariates, such as trade activity. ${ }^{50}$ Second, the only subnational quantitative analysis of the correlates of preliminary reference activity confirmed that these findings also hold at the subnational level. ${ }^{51}$ That is, population appears to be the best and most robust predictor of structural demand for EU law via the preliminary reference procedure. ${ }^{52}$ This is unsurprising, as claims for the judicial enforcement of EU law are more likely to arise in more populous areas, where disputes are also concentrated.

To operationalize the role of institutional change agents, we identify a measure of the presence of the European legal field, as emphasized in the causal arguments of socio-legal scholars. ${ }^{53}$ Although no single measure can capture the spatial growth of the European legal field, the spread of Eurofirms - corporate law firms with recognized expertise in

\footnotetext{
${ }^{48}$ Below (see figures 3-5 and accompanying text), we offer a more detailed analysis of the evolving spatial penetration of the EU legal order in France, (West) Germany, and Italy.

${ }^{49}$ Vink, Claes, and Arnold 2009; Kelemen and Pavone 2016.

${ }^{50}$ Vink, Claes, and Arnold 2009; Kelemen and Pavone 2016.

${ }^{51}$ Kelemen and Pavone 2016.

${ }^{52}$ Additionally, data on other structural variables, such as GDP per capita or export activity, are only available at the NUTS3 level in recent years, whereas Eurostat data on population at the NUTs3 level are available for all three of the countries of interest beginning in the mid-1970s onward, which allows us to increase the number of observations and the temporal reach of our analysis.

${ }^{53}$ Vauchez and de Witte 2013.
} 
EU law-provides a powerful indicator. ${ }^{54}$ We thus rely on an original geocoded data set of the number of firms in a given NUTS3 region (in a given year) ranked in Legal 500 and Chambers Europe. These firms are usually large (one hundred-plus lawyers), global (with offices in multiple countries and cities - particularly in Brussels, where most EU institutions are located), and boast prominent lawyers holding prestigious positions in nearby law schools. In short, we treat the number of branch offices of one of these Eurofirms in a given NUTS3 region to be a reasonable proxy for the heightened presence of repeat players mobilizing for institutional change and for the construction of the European legal field via the preliminary reference procedure.

For our econometric analysis, we use a negative binomial regression model-a standard technique for the analysis of over-dispersed count data (like preliminary references to the ECJ). We regress the yearly NUTS3 reference rate on a NUTS3 district's logged population and the number of branch offices of ranked Eurofirms operating within said district..$^{55}$ To account for unobserved inter-year variation, such as the influence of well-publicized EU treaty changes, we include year fixed effects. Crucially, we also include country fixed effects to see whether unobserved, country-level factors, such as the structure of a state's judiciary, have a significant effect on reference activity even when accounting for population and the role of Eurofirms. Table 2 displays the results of this analysis based on more than nineteen thousand regionyear observations.

As Table 2 demonstrates, the density of Eurofirms and population levels are positively and significantly related to the frequency of use of the preliminary reference procedure (at the 99 percent confidence level). But there remain significant, unobserved country-level effects that influence preliminary reference activity (the partial regression coefficient for the indicator [or dummy] variables for Italy and Germany, with France serving as the baseline, are both statistically significant at the 99 percent confidence level). In the sections below, we conduct a threecountry comparison to disentangle this unobserved variation into its spatial and temporal components and to assess its congruence with our hypotheses stressing the causal role of domestic judicial organization.

\footnotetext{
${ }^{54}$ The data were obtained via the websites of the firms ranked by either the Legal 500 or Chambers Europe. We consider the founding date of a branch office in a given city to be a relatively accurate proxy of the heightened presence of the European legal field in that location.

${ }^{55}$ Rankings are for 2016. For each ranked firm, its website, Chambers Europe and Legal 500, and newspaper articles were scoured for the date when firm branch offices were opened.
} 
TABLE 2

Negative Binomial Regression of Yearly References

on the Number of Ranked Eurofirms and Logged Population (at The NUTS3 Level), 1975-2013 a

\begin{tabular}{|c|c|}
\hline Independent Variables & DV: No. Yearly Refs (NUTS3) \\
\hline No. ranked Eurofirms & $\begin{array}{l}0.104^{* * * *} \\
(7.7)\end{array}$ \\
\hline $\ln$ (Population) & $\begin{array}{l}1.617^{* * *} \\
(33.32)\end{array}$ \\
\hline Italy dummy & $\begin{array}{l}0.417^{* * *} \\
(4.14)\end{array}$ \\
\hline Germany dummy & $\begin{array}{c}1.27^{* * * *} \\
(13.62)\end{array}$ \\
\hline Year fixed effects & yes \\
\hline Constant & $\begin{array}{l}-24.25^{* * *} \\
(-34.01)\end{array}$ \\
\hline Observations & 19440 \\
\hline
\end{tabular}

\section{Domestic Judiciaries and the Spatial Coverage of Reference Activity Over Time}

The presence of unobserved variation across German, French, and Italian preliminary references, particularly when controlling for structural demand and the presence of institutional change agents, requires us to consider how the preexisting institutional landscape of member states may channel, constrain, or facilitate the spread of the EU legal order. In particular, H1a posits that the more hierarchically centralized a state's judiciary, the more variable should be the pace of spatial diffusion of EU law. If high courts in these judicial orders signal to lower courts that they support their engagement with EU law, this should encourage the rapid spread of preliminary reference activity. Conversely, if these high courts seek to assert greater control over reference activity or to contain it, lower courts will likely fall into line and reduce use of the procedure. In contrast, in decentralized judiciaries we expect the spatial diffusion of the reference procedure to be a more incremental, bottom-up process 
that is resistant to the vicissitudes of national politics or the shifting preferences of superior courts.

To shed some descriptive light on the face validity of H1a, we generate a fifty-kilometer buffer around each referring court in France, Italy, and Germany for the five decades spanning 1964 to 2013. These buffers visually display the proportion of each country's territory (by decade) that is within a daily commuting distance of a court that has demonstrated its willingness to submit references to the ECJ. Figures 2-4 map these buffers by decade across France, Italy, and Germany.

A visual inspection of the figures reveals some patterns supportive of H1a. In France we note how negligible reference activity in the 1960s (with less than 7 percent of France's territory within a fifty-kilometer buffer) is quickly replaced by a rapid spatial diffusion of reference activity between 1974 and 1993 (peaking at over 66 percent of French territory falling within a fifty-kilometer buffer). Thereafter, however, the process seems to reverse itself, with a noticeable decline in spatial coverage across the past two decades (falling to 38.8 percent of territory within a fifty-kilometer buffer from 2004 to 2013). In contrast, in Italy - and especially in Germany - reference activity has been rising steadily (with spatial coverage levels [territory within a fifty-kilometer buffer] rising from 19.3 percent to 72.4 percent in Italy and from 32.5 percent to 74.5 percent in Germany) and lacks any significant spikes or reversals in the process.

To provide more direct evidence of the greater variability of spatial coverage in France compared to Italy and especially to Germany, we compute the mean five-year percentage change in the territory falling within a fifty-kilometer buffer for each country. ${ }^{56}$ We use five-year intervals to capture more fine-grained, within-decade shifts in spatial diffusion. Figure 5 displays the results: consistent with $\mathrm{H} 1 \mathrm{a}$, the average five-year percentage change in the spatial coverage of reference activity is 76.2 percent in France, 56.6 percent in Italy, and only 20.4 percent in Germany. ${ }^{57}$ The variability in these percentage changes is also greatest in France. For example, from 1969 to 1973 only 4.5 percent of French territory lay within fifty kilometers of a referring court, but from 1974 to 1978 this value rose rapidly to 23.57 percent-a percentage change of 482 percent. In contrast, in Germany the highest five-year

\footnotetext{
${ }^{56}$ More precisely, we compute the absolute value of the five-year mean percentage change in territorial coverage, since both increases and decreases in coverage constitute variability in spatial diffusion.

${ }^{57}$ In Appendix A, we provide the results for a one-way, two-sample $t$-test for difference in means. Although the results are just shy of statistical significance, this is likely due to small sample size. Kelemen and Pavone 2018b.
} 


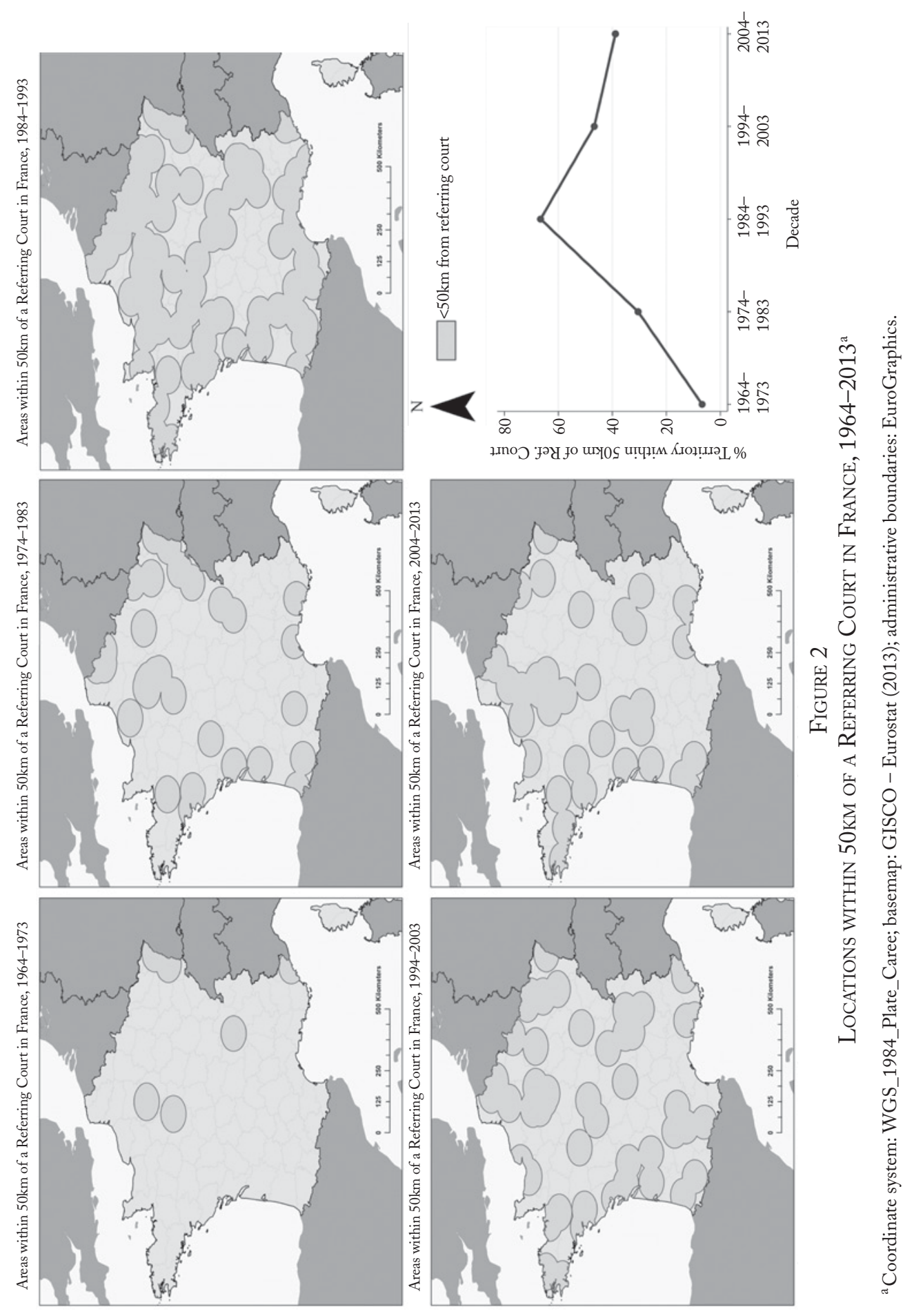



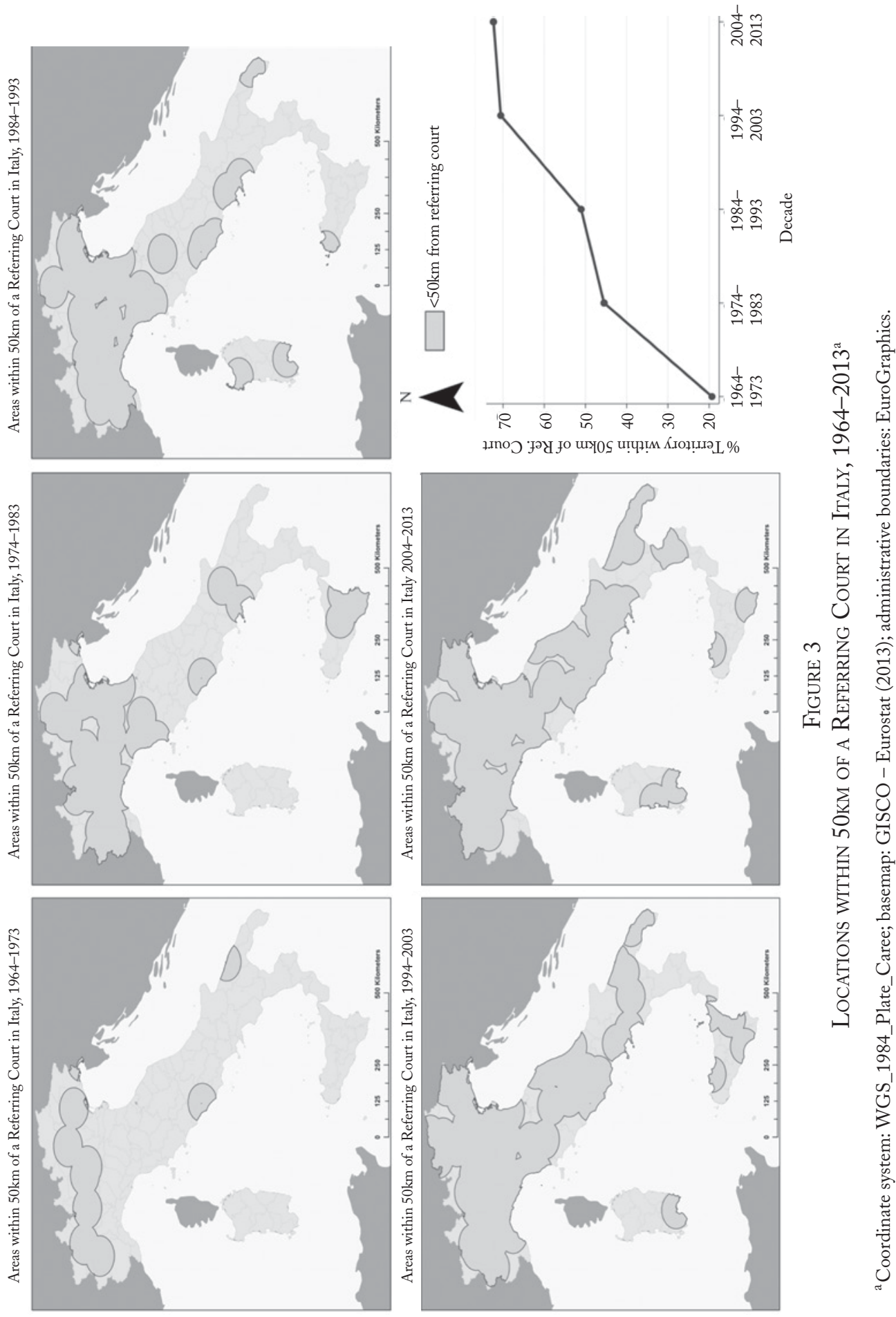

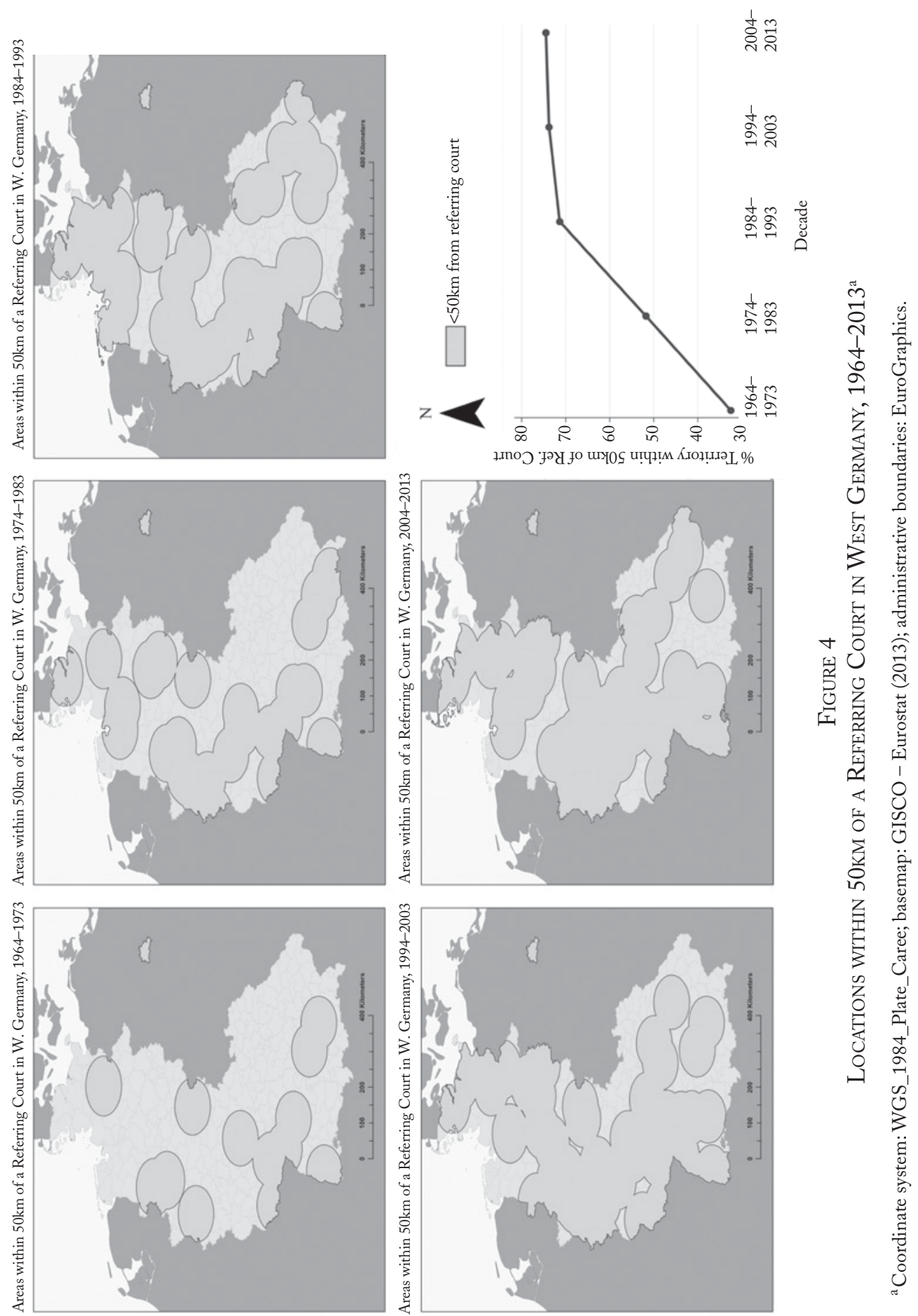


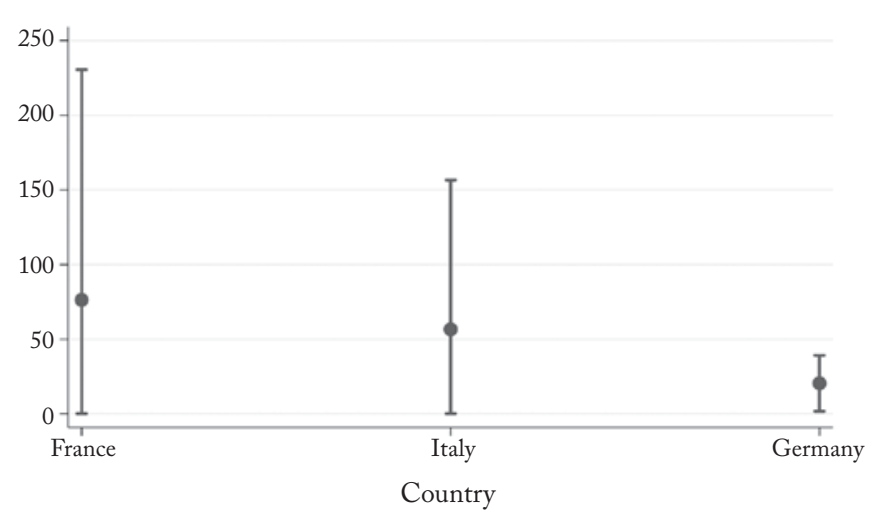

- Mean \% change in coverage $\longmapsto$ Range (+/- one SD, non-negative)

FiguRe 5

Temporal Variability in Spatial Coverage of Reference Activity in France, ItALY, AND Germany

percentage change in territorial coverage is only 47.8 percent (from the 1964 to 1968 period to the 1969 to 1973 period).

Note that another observable implication of $\mathrm{H} 1 \mathrm{a}$ is that the greater temporal variability in spatial diffusion in a centralized system should be due to the greater sensitivity of these judiciaries to the shifting preferences of supreme courts, which may be influenced by the shifting dynamics of national, interbranch politics. One observable implication is that supreme courts should - if they decide it is in their interest - be better able to monopolize the reference procedure in centralized judiciaries, whereas in decentralized systems reference activity from lower courts should incrementally grow and remain relatively unaffected by pressures from the apex of the judiciary. Although a detailed parsing of the historical record to assess these implications falls outside the scope of our paper, a preliminary overview of the evidence is supportive. That is, while supreme courts in all three countries have tried to assert greater control over the procedure in recent years (see Appendix $\mathrm{C}$ of the supplementary material), this trend is clearest in the French case. ${ }^{58}$ Comparatively, only in France has the growing reference activity by supreme courts occurred while the spatial coverage of the reference procedure has again become more concentrated (in Paris). (See Figures 2-4.)

A brief analysis of the historical record suggests the reason for these

${ }^{58}$ Kelemen and Pavone 2018b. 
shifts in reference activity in France. While "members of the Conseil d'État [the supreme administrative court...] made it clear that they were waiting for a political directive on what to do with EC law supremacy" in the 1970s, the Cour de Cassation (the supreme civil court) was more willing to refer cases to the ECJ. ${ }^{59}$ Following the Cour de Cassation's lead, in the 1970s the lower civil courts scattered throughout France began to refer cases to the ECJ. The French Parliament acted swiftly, passing legislation in 1979 prohibiting French courts from setting aside national law..$^{60}$ With the Conseil d'État resistant, the Cour de Cassation under political pressure, and the Parliament hostile to the ECJ's authority, a normative consensus resisting the supremacy of EU law developed at the apex of the French state, and it is unsurprising that reference activity from supreme courts stalled in the 1980s. With their judicial superiors reticent or hostile to embracing the ECJ's authority, this trend was only partially offset by a timid continuation of references by a few lower civil courts. In contrast, in Italy and particularly in Germany, lower court reference rates grew steadily during this period. Reference rates in France only began to pick up again in the late 1980s, when a newfound push for European integration was supported by the Mitterrand government, influencing supreme court judges - particularly at the Conseil d'État - to have a change of heart. Arguing before the Conseil d'État in the 1989 Nicolo case, the Commissaire du Gouvernement, Patrick Frydman, ${ }^{61}$ successfully cajoled his colleagues to embrace the use of the reference procedure. The trickle of reference activity by French courts was denying France an adequate voice over the development of EU law, Frydman argued, because "[as] far as foreign courts are concerned ... all I would say is that your Court is now the last which formally refuses to apply Community measures which are contracted by later laws." ${ }^{2} \mathrm{He}$ concluded, "It cannot be repeated often enough that the era of the unconditional supremacy of internal law is now over." 63

This political shift had a clear effect on French reference activity. The Cour de Cassation gained renewed confidence to wield the Ecj's

${ }^{59}$ Alter 1996, 486. See also Plötner 1998.

${ }^{60}$ Alter 1996, 475.

${ }^{61}$ Despite the title, the Commissaire du Gouvernement is a fellow judge who provides an advisory opinion in a given case before the Conseil d'État (Alter 1996, 483-4). Nevertheless, with the Mitterrand government broadly supportive of the agenda for further European integration pioneered by Jacques Delors and the European Commission (Gompert and Larrabee 1998, 112), political pressure mounted on the Conseil d'État to change its approach.

${ }^{62}$ Weiler 1994, 522.

${ }^{63}$ Alter 1996, 469. 
preliminary rulings against the National government, ${ }^{64}$ and the Conseil d'État quickly began to follow suit. In response to the Conseil d'État's newfound openness to EU law, lower administrative courts also began to refer more cases to the ECJ (more than doubling from twenty-six references from 1964-1989 to sixty-three from 1990-2013). But importantly, high courts remain firmly in the driver's seat of this process of judicial cooperation with the European Court. In the past decade, French supreme courts have referred a majority of all references originating from France, disproportionately concentrating the judicial enforcement of EU law in Paris.

In keeping with $\mathrm{H} 1 \mathrm{a}$, in France's more centralized structure, the shifting preferences of high courts led to greater temporal variability in the domestic penetration of European law than that observed in the more decentralized systems of Italy and Germany. In all three legal orders, judges in at least one supreme court tried at some point to limit domestic judicial dialogue with the ECJ. ${ }^{65}$ What differs across the three cases is the degree to which such efforts by apex courts succeeded in influencing the overall level of reference activity by lower courts and the geographic spread of reference activity across the territory of the country. Whereas these signals from the apex courts in France clearly influenced the willingness of lower courts to dialogue with the ECJ, in Italy and particularly Germany, a steady increase in references from lower courts in some subnational regions suggests that supreme courts had little influence over their inferiors' growing willingness to collaborate with the ECJ to enforce EU law. And even as German and Italian supreme courts have also increasingly sought to become the ECJ's primary interlocutors, lower courts have not ceded their ground, continuing to send a steady (Italy) or growing (Germany) stream of cases to the European Court. ${ }^{66}$

\section{Domestic Judiciaries and InTERregional VARiation In THE Diffusion of EU LaW Litigation}

Our next hypothesis (H1b) builds on the foregoing analysis by positing that whereas decentralized judiciaries should witness lower levels of

${ }^{64}$ Obermaier 2008, 743-44.

${ }^{65}$ The German Federal Constitutional Court and the German Federal Fiscal Court's uneasy relationships with the ECJ have been extensively documented by Alter 2001, Lindseth 2010, and Davies 2012; see Fontanelli and Martinico 2010 for parallel analyses of the Italian Constitutional Court's shifting attitudes vis-à-vis the ECJ.

${ }^{66}$ Note that the steady increase in references in Germany cannot exclusively be attributed to more consistent support for EU integration across governments over time. First, even if such support could explain low levels of temporal variation in preliminary reference rates, it could not explain why there 
intertemporal variability in the spatial diffusion of the reference procedure, they should at the same time encourage greater interregional variation. The logic behind this hypothesis is that centralized organizations tend to promote institutional isomorphism and homogeneity of practice, whereas decentralized organizations permit more locationspecific and heterogeneous practices.

An observable implication of $\mathrm{H} 1 \mathrm{~b}$ is that yearly subnational reference activity in Germany should be more variable across regions than in France, with Italy lying somewhere in between. We can assess this if we compare the standard deviations of the average number of yearly references per NUTS 3 region across the three countries. However, to achieve a valid comparison we need to take two things into account. First, our prediction may be artificially validated because the German judiciary disperses its supreme courts across its territory-in Berlin (through 2002), Erfurt, Leipzig, Karlsruhe, Kassel, and Munich-whereas the Italian and French judiciaries concentrate their supreme courts in their respective capital cities. This might artificially inflate the interregional variation in reference activity in Germany. As a result, in our analysis we only consider references submitted by courts of first instance and nonfinal appeal. Second, we must be careful to take into account countrylevel differences in baseline reference activity. To this end, we compute the average yearly reference rate for each NUTS3 region as a percentage of the country mean (which is set to one hundred). This allows us to compare the inter-NUTS 3 variation relative to the national mean across the three countries. To visualize the results, Figure 6 displays the size of the standard deviation relative to the mean reference rate for Italy, France, and Germany.

Overall, Figure 6 supports H1b: relative to its baseline level of reference activity, Germany has substantially greater variation in the number of yearly references originating from lower courts in its districts than does Italy for lower courts in its provinces or France for lower courts in its departments. Specifically, the standard deviation around the mean is 226 percent for France, 303 percent for Italy, and 440 percent for Germany. A one-sided, independent-samples F-test for equality of variances finds that the French standard deviation is significantly lower than the German standard deviation at the 99 percent confidence level (the F-test table is reported as Appendix A in the supplementary

remains stark subnational spatial variation in national court referrals to the ECJ (as the next section demonstrates). Second, since both German and Italian governments have consistently supported EU integration over time, differences in temporal variation in reference rates between the two countries cannot be attributed to varying government support for EU integration. 


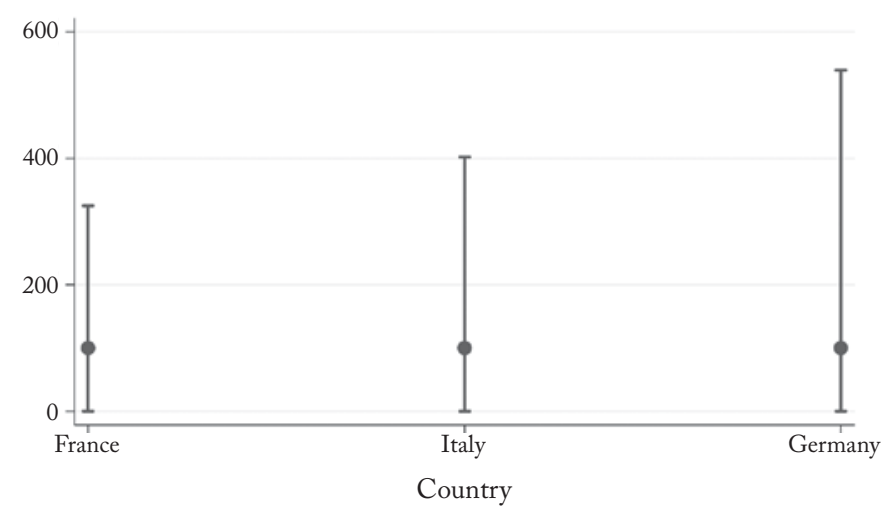

- NUTS3 yearly ref. rate (mean=100) $\longmapsto$ Range (+/- one SD, non-neg.)

FiguRe 6

Spatial Variation in Reference Rates in France, Italy, and Germany ${ }^{a}$

${ }^{a}$ The yearly NUTS3 reference rate for each country was computed by averaging the mean yearly references in each of their NUTS3 jurisdictions. Each country's mean reference rate was then standardized by dividing each NUTS3 region's rate by the country average, setting each country's average to 100 .

material). Note that this finding is not driven by demographic pressures: Performing a parallel analysis for variation in population levels across NUTS 3 jurisdictions in the three countries reveals comparable levels of subnational population variability (see Appendix D in the supplementary material).

\section{Domestic Judiciaries And Issue-Specific Clustering of REFERENCE ACTIVITY}

Our theory of the subnational penetration of the EU legal order sheds light not only on patterns of dispersion across the territory of member states, but also on patterns of spatial clustering in what geographers call hot spots. Hot spots reflect a form of spatial autocorrelation in which locations with significantly higher values for the dependent variable (compared to the global mean) are clustered together. H2a posits that hot spots of preliminary reference activity focused on particular areas of law should emerge within member states. The underlying logic is that clusters of elevated judicial enforcement of EU law may emerge due to a common exposure to local socioeconomic conditions. That is, we might expect clusters of litigation relating to fisheries policy to emerge 
in major coastal fishing communities and an absence of such litigation in landlocked areas. Further, path-dependent processes involving local knowledge spillovers and other agglomeration effects may help to sustain these hot spots over time. Relatedly, our final hypothesis, H2b, adds that this form of issue-specific spatial clustering should be more pronounced in countries with decentralized judiciaries compared to those with centralized ones. The underlying logic follows directly from H1b: in states with decentralized judiciaries, the practice of EU law should be more responsive to local socioeconomic conditions, whereas states with centralized judiciaries should promote more standardized judicial practices.

To assess these two hypotheses, we focus on EU litigation in four of the most commonly litigated areas of EU law: (1) agriculture-related; (2) competition, taxation, and freedom of establishment-related; (3) free movement of goods, services, and workers-related; and (4) social security and social provisions-related references. These non-mutually exclusive issue categories are based on the coding scheme used by Alec Stone Sweet and Thomas Brunell in their path-breaking, crossnational analysis of the reference procedure. ${ }^{67} \mathrm{We}$ limit our analysis to courts of first instance and initial appeal to avoid distortions associated with the location of high courts that may artificially validate our claims regarding issue-specific spatial clustering. Across the three countries, this yields a total of 684 references related to agriculture; 924 references related to competition, taxation, and freedom of establishment; 745 references related to the free movement of goods, services, and workers; and 343 references related to social security and social provisions.

To identify spatial clustering, we employ a leading measure of spatial autocorrelation: the Getis-Ord Gi* ${ }^{68}$ This statistic identifies whether statistically significant high or low polygon values for a particular variable (compared to the global mean) are clustered spatially within a given fixed distance band surrounding each polygon, thus revealing statistically significant hot spots and cool spots. For our analysis, the polygons comprise NUTS3 regions, the fixed distance band is computed by running a global spatial autocorrelation analysis (using the Global Moran's I statistic) to identify the spatial distance at which clustering is maximized, and the dependent variable is the total number of references per NUTS3 region related to the four issue areas under analysis. Since NUTS3 regions differ somewhat in size both within countries and

\footnotetext{
${ }^{67}$ Stone Sweet and Brunell 1998. We do not conduct parallel analyses for other EU legal domains because they generate litigation rates that are too low to assess spatial clustering with confidence.

${ }^{68}$ Getis and Ord 1992.
} 
between countries, this analysis may be affected by what geographers term the "modifiable areal unit problem"69 — or the fact that "as the [geographic] unit of analysis varies, so too will our results." ${ }^{\prime 70}$ We thus replicate the analysis using a standardized polygon grid as a robustness check, without any notable change in the results (see appendixes $\mathrm{E}-\mathrm{G}$ of the supplementary material). This attenuates concerns that the modifiable areal-unit problem is biasing our inferences.

Figures 7 through 9 display the geospatial hot-spot analysis for France, Italy, and Germany. Overall, the results strongly support both $\mathrm{H} 2 \mathrm{a}$ and $\mathrm{H} 2 \mathrm{~b}$. First, congruent with $\mathrm{H} 2 \mathrm{a}$, the clustering of overall preliminary reference activity (the first map on the upper left of each figure) masks issue-specific differences in the political geography of the use of the reference procedure: in none of the three countries is the generic hotspot map for all references the same as all of the issue-specific hot-spot maps. In France, agricultural and social security/provisions references are clustered in a slightly different spatial pattern compared to overall reference clustering; in Italy and Germany, the clustering patterns for all four issue areas differ to varying degrees from the generic hot-spot map.

At the same time, it is clear that as $\mathrm{H} 2 \mathrm{~b}$ would predict, the issuespecific differences in hot-spot patterns in centralized France are very minimal compared to those in Italy and particularly in highly decentralized Germany. Even when omitting all supreme court references, reference activity across all issue areas is overwhelmingly concentrated in Paris, which emerges as a statistically significant hot-spot of agricultural $(\mathrm{n}=25)$, free movement $(\mathrm{n}=69)$, social $(\mathrm{n}=14)$, and competition $(n=24)$ references with 99 percent confidence. This is particularly striking vis-à-vis free movement references. One would expect Marseille, the largest port in France, to emerge as a hot-spot for free movement references. Instead, courts in Marseille only referred a single case to the ECJ on the matter. Indeed, the judicial enforcement of EU law remains predominantly clustered in the capital, such that Parisian judges disproportionately influence the judicial dialogue with the ECJ compared to those in other French courts. These conclusions are bolstered when we compare the French results to those in Italy and Germany.

In Italy, the capital city of Rome is, not unlike its French counterpart, very active across all issue domains. But two differences vis-à-vis the French case readily emerge. First, the degree to which greater Rome

\footnotetext{
${ }^{69}$ Gleditsch and Weidmann 2012, 476.

${ }^{70}$ Soifer forthcoming.
} 

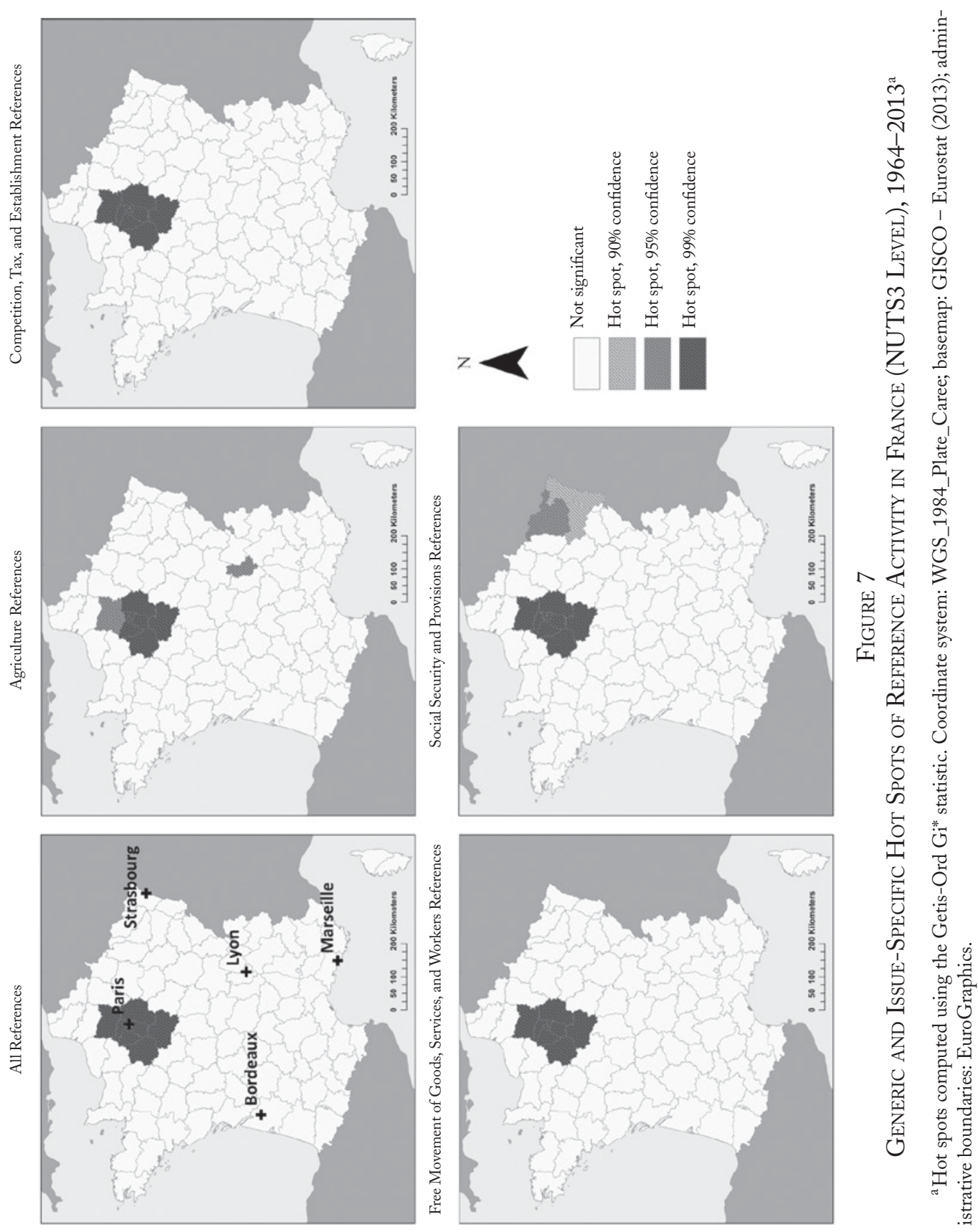

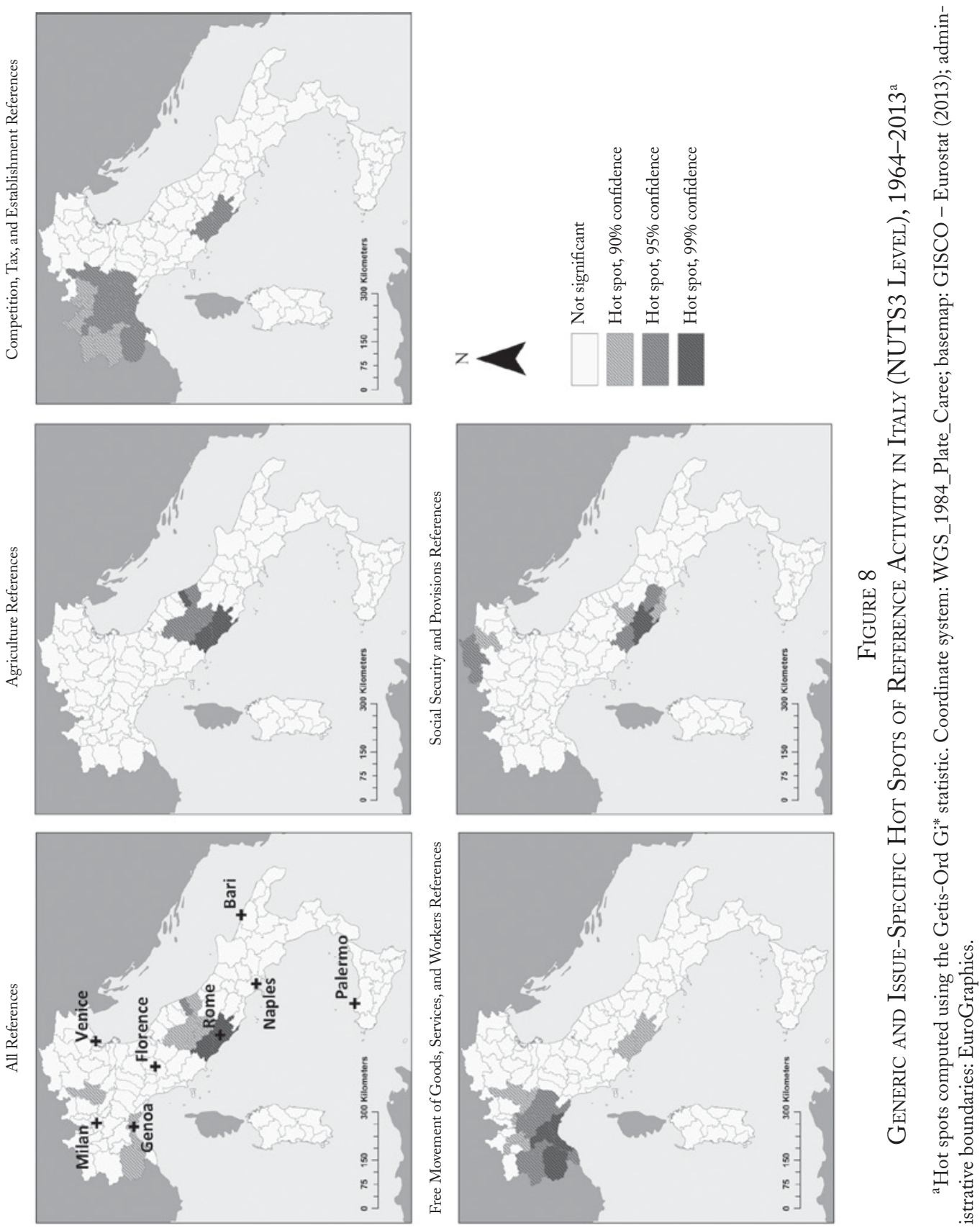

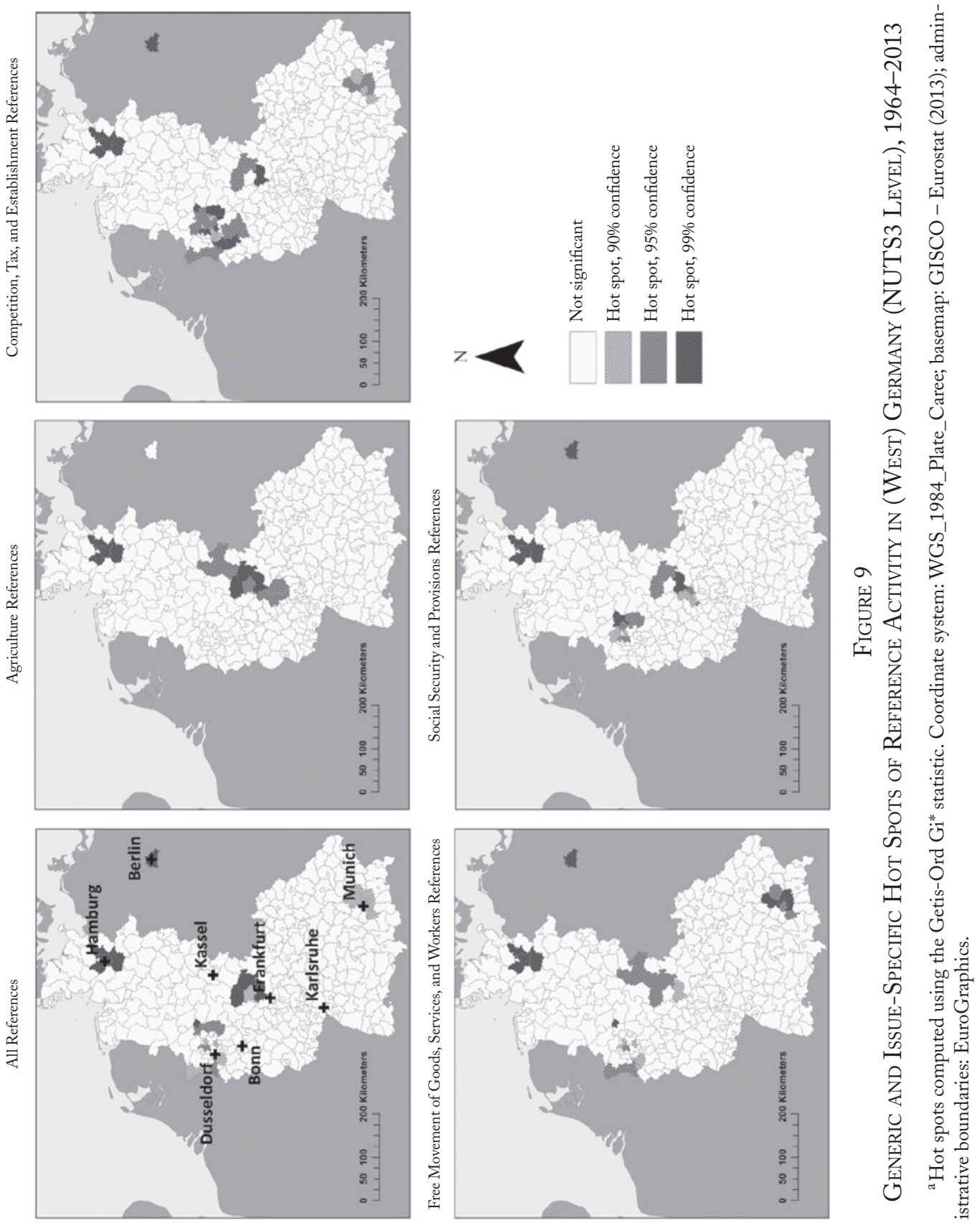
is a hot-spot of reference activity varies somewhat across issue areasranging from 99 percent confidence for agriculture and social references to only 90 percent confidence for free movement references. Second, with the exception of agriculture references, Rome fails to emerge as the only hot-spot of reference activity: for free movement and competition references, the industrial triangle of Turin, Milan, and Genoa is an equal if not more significant hot-spot than is Rome. This is unsurprising considering that Milan and Turin are the industrial hubs of Italy and that Genoa has long been the country's main port and one of the most active port cities in Mediterranean Europe. For competitionrelated references, Milan, which is the financial center of Italy, also lies at the center of a significant hot-spot $(n=62)$. And for social security and provisions references, activity from the Trentino-Alto Adige near the city of Bolzano emerges as a significant hot spot, while the hot-spot including Rome is shifted slightly southeastward due to higher social reference activity from the poorer city of Naples $(n=9)$.

Finally, issue-specific clustering in reference activity is most evident in Germany, where none of the issue-specific hot-spot maps align exactly with the generic hot-spot map. Here, very distinct political geographies are present, depending on which set of EU rules are being litigated and judicially enforced. Most hot spots appear for some issue areas and disappear when the litigation of other EU rules are considered. For competition-related references, it is North Rhine-Westphalia that is the most extensive and intense hot-spot of reference activity. Here, too, we see a responsiveness of reference activity to local socioeconomic context. North Rhine-Westphalia has long been the industrial core of the German economy, and it is currently home to twenty-four of the fifty largest German companies. ${ }^{71}$ Tellingly, Frankfurt - the financial hub of Germany - is also home to a hot-spot of competition-based reference activity $(\mathrm{n}=34)$, as is Munich ( $\mathrm{n}=31)$, which may signal that its federal patent court is generating positive agglomeration effects in Munich's lower courts. And for free movement references, it is unsurprising that Hamburg - the primary port of Germany - is a significant hot-spot of reference activity $(n=55)$. Notably, the industrial core of North RhineWestphalia, whose economy originally centered on the production and shipping of coal and steel, is also speckled with significant hot spots of free movement references, as is Munich $(n=46)$, which is located within 100 miles of the Swiss, Austrian, and Czech borders.

It is not our objective to provide a fine-grained account of every

${ }^{71}$ European Commission 2016. 
hot-spot revealed in Figures 7-9. Doing so would require further research based on a mixed-method design that combines fine-grained socioeconomic indicators at the local level with historical and interview data to conduct comparative case studies of specific hot spots. The more modest aims we pursue are to provide some plausible interpretations for our Getis-Ord $\mathrm{Gi}^{*}$ results, and to underscore that the judicial enforcement of EU law through the reference procedure exhibits issue-specific political geographies conditioned by the organization of domestic judiciaries.

\section{CONCLUSION}

By developing a historical institutionalist approach aimed at explaining the political geography of legal integration, this article is able to visualize and analyze the spatiotemporal spread of European law in a way previous accounts could not. We demonstrate that while the judicial reach of the EU legal order has indeed spread spatially within member states due to the growing structural demand for EU law and the mobilization of institutional change agents, the pace and pattern of its penetration continues to be conditioned by enduring domestic institutions. Hence, while EU legal development and the case law of the ECJ may often escape direct control by member-state governments, ${ }^{72}$ the reality is that the judicial enforcement of EU law across time and space continues to be shaped by the design of national institutions.

More generally, these results yield new theoretical insights into the development of the infrastructural power of modern law-states like the $\mathrm{EU},{ }^{73}$ highlight avenues for future research on where political development through law is at greatest risk of retrenchment, and suggest new methodological approaches to the study of institutional change.

Theoretically, the results demonstrate how polities may construct their infrastructural power by relying on incremental processes of layering and conversion, but must then contend with the path-dependent influence of preexisting institutional structures. Although the design of the French, Italian, and German judiciaries largely predates the founding of the European Community, these varied institutional forms have nonetheless mediated and conditioned the "Europeanization" 74 of domestic judicial practice across space and time. Broadly, the layering of supranational rules atop unitary, centralized states with hierarchically

\footnotetext{
${ }^{72}$ Burley and Mattli 1993; Alter 1996; Stone Sweet 2000.

${ }^{73}$ Kelemen 2016.

${ }^{74}$ Jacoby 2002; Schimmelfennig and Sedelmeier 2005.
} 
streamlined judiciaries favors a more spatially homogeneous process of institutional change. However, the judicial enforcement of supranational rules will be more sensitive to the shifting preferences of top-level state institutions, such as supreme courts and national parliaments. The reverse holds for federal states with decentralized judiciaries. While decentralization facilitates the bottom-up conversion of national courts into European courts and insulates this process from top-down interference, it also tends to concentrate institutional change within subnational hot spots. By contrast, other areas may remain "law deserts" 75 where supranational rules are seldom converted into local practice. As a result, neither a centralized nor decentralized judicial structure is an unequivocally better $\mathrm{fit}^{76}$ for the process of political development through law. Nevertheless, our analysis does suggest that the political geography of legal integration - and consequently, the enforcement of new legal rights - may be more temporally vulnerable to retrenchment ${ }^{77}$ in centralized states. This implication could be a fertile avenue for future research, particularly given recent efforts by some Eurosceptic memberstate governments to limit the domestic judicial enforcement of EU law. ${ }^{78}$

Finally, methodologically this article constitutes a significant advance in combining geospatial methods with the theoretical study of legal integration and political development. We test our hypotheses concerning the spread of the EU legal order across space and time using an original geocoded data set of preliminary references and a set of tools-GIS and spatial statistics - that are novel in the study of European legal integration and, with some important exceptions, ${ }^{79}$ remain relatively rare in the fields of socio-legal studies and historical institutionalism. We hope other scholars will build on this geospatial approach to explore other aspects of the spread of the EU legal order and to study other processes of political development through law. When combined with careful historical analysis, such a research agenda would bolster scholars' ability to understand and, quite literally, to see how institutional change is structured across space and time.

\footnotetext{
${ }^{75}$ Pavone 2015.

${ }^{76}$ Börzel and Risse 2003.

${ }_{77}$ Pierson 1995; Hacker 2004; Staszak 2014.

${ }^{78}$ Specifically, since the domestic judicial enforcement of a supranational legal order like the EU is more diffuse in decentralized states, it is likely to be more temporally secure and difficult to co-opt than in centralized states. This finding has clear-and worrying-implications for recent efforts by some populist governments in highly centralized states, such as Hungary and Poland, to resist the domestic application of EU law by curbing the authority (or packing the membership) of their respective judiciaries (Pech and Scheppele 2017).

${ }^{79}$ See Ingram 2016.
} 


\section{SupPlementary Material}

Supplementary material for this article can be found at https://doi.org/10.1017 /S0043887118000011.

\section{REFERENCES}

Alter, Karen. 1996. “The European Court's Political Power.” West European Politics 19, no. 3: 458-87. doi: 10.1080/01402389608425146.

- 2001. Establishing the Supremacy of European Law: The Making of an International Rule of Law in Europe. New York, N.Y.: Oxford University Press.

Alter, Karen, and Laurence Helfer. 2017. The Law and Politics of the Andean Tribunal of Justice. New York, N.Y.: Oxford University Press.

Audretsch, D. B. 1998. "Agglomeration and the Location of Innovative Activity." Oxford Review of Economic Policy 14, no. 2: 18-29. doi: 10.1093/oxrep/14.2.18.

Bell, John. 2006. Judiciaries Within Europe: A Comparative Review. New York, N.Y.: Cambridge University Press.

Bennett, Andrew, and Jeffrey Checkel, eds. 2014. Process Tracing: From Metaphor to Analytic Tool. New York, N.Y.: Cambridge University Press.

Berman, Harold J. 1983. Law and Revolution: The Formation of the Western Legal Tradition. Cambridge, Mass.: Harvard University Press.

Börzel, Tanja A., and Thomas Risse. 2003. "Conceptualizing the Domestic Impact of Europe." In Kevin Featherstone and Claudio M. Radaelli, eds., The Politics of Europeanization. New York, N.Y.: Oxford University Press.

Boucoyannis, Deborah. 2005. "Land, Courts, and Parliaments: The Hidden Sinews of Power in the Emergence of Constitutionalism." Ph.D. diss., University of Chicago.

Burley, Anne-Marie, and Walter Mattli. 1993. "Europe before the Court: A Political Theory of Legal Integration.” International Organization 47, no. 1: 41-76. doi: $10.1017 /$ S0020818300004707.

Cammett, Melanie, and Sukriti Issar. 2010. "Bricks and Mortar Clientelism: Sectarianism and the Logics of Welfare Allocation in Lebanon." World Politics 62, no. 3 (July): 381-421. doi: 10.1017/S0043887110000080.

Carrubba, Clifford J., Matthew Gabel, and Charles Hankla. 2008. "Judicial Behavior under Political Constraints: Evidence from the European Court of Justice." American Political Science Review 102, no. 4: 435-52. doi: 10.1017/S000 3055408080350.

Casonato, Carlo, and Jens Woelk, eds. 2008. Costituzione della Repubblica italiana. Trento, Italy: Università di Trento. At http://www.jus.unitn.it/dsg/pubblica zioni/costituzione/costituzione\%20genn2008ita.pdf, accessed April 13, 2018.

Chalmers, Damian, and Mariana Chaves. 2012. "The Reference Points of EU Judicial Politics." Journal of European Public Policy 19, no. 1: 25-42. doi: 10.1080 /13501763.2012.632125.

Cho, Wendy K. Tam, and James G. Gimpel. 2012. “Geographic Information Systems and the Spatial Dimensions of American Politics." Annual Review of Political Science 15: 443-60. doi: 10.1146/annurev-polisci-031710-112215.

Crowe, Justin. 2012. Building the Judiciary: Law, Courts, and the Politics of Institutional Development. Princeton, N.J.: Princeton University Press. 
Davies, Bill. 2012. Resisting the European Court of Justice. New York, N.Y.: Cambridge University Press.

European Commission. 2016. "North Rhine-Westphalia." At https://ec.europa .eu/growth/tools-databases/regional-innovation-monitor/base-profile/north -rhine-westphalia, accessed September 8, 2016.

Feldman, Maryann P. 1999. "The New Economics of Innovation Spillovers and Agglomeration: A Review of Empirical Studies.” Economics of Innovation and New Technology 8, 1-2: 5-25. doi: 10.1080/10438599900000002.

Fioretos, Orfeo. 2011. Creative Reconstructions: Multilateralism and European Varieties of Capitalism after 1950. Ithaca, N.Y.: Cornell University Press.

Fontanelli, Filippo, and Giuseppe Martinico. 2010. "Between Procedural Impermeability and Constitutional Openness: The Italian Constitutional Court and Preliminary References to the European Court of Justice." European Law Journal 16, no. 3: 345-64. doi: 10.1111/j.1468-0386.2010.00511.x.

Franzese, Robert, and Jude C. Hays. 2008. "Interdependence in Comparative Politics: Substance, Theory, Empirics, Substance." Comparative Political Studies 41, 4-5: 742-80. doi: 10.1177/0010414007313122.

Frymer, Paul. 2008. "Law and American Political Development." Law and Social Inquiry 33, no. 3: 779-803. doi: 10.1111/j.1747-4469.2008.00121.x.

. 2017. Building an American Empire: The Era of Territorial and Political Expansion. Princeton, N.J.: Princeton University Press.

Fukuyama, Francis. 2012. The Origins of Political Order: From Prehuman Times to the French Revolution. New York, N.Y.: Farrar, Straus and Giroux.

Garrett, Geoffrey. 1992. "International Cooperation and Institutional Choice: The European Community's Internal Market." International Organization 46, no. 2: 533-60. doi: 10.1017/S0020818300027806.

Getis, Arthur, and J. K. Ord. 1992. "The Analysis of Spatial Association by Use of Distance Statistics.” Geographical Analysis 24, no. 3: 189-206. doi: 10.1111 /j.1538-4632.1992.tb00261.x.

Gleditsch, Kristian Skrede, and Michael D. Ward. 2006. "Diffusion and the International Context of Democratization." International Organization 60, no. 4: 911-33. doi: 10.1017/S0020818306060309.

Gleditsch, Kristian Skrede, and Nils D. Weidmann. 2012. "Richardson in the Information Age: Geographic Information Systems and Spatial Data in International Studies." Annual Review of Political Science 15, June: 461-81. doi: 10.1146/annurev-polisci-031710-112604.

Gompert, David C., and F. Stephen Larrabee. 1998. America and Europe: A Partnership for a New Era. New York, N.Y.: Cambridge University Press.

Hacker, Jacob S. 2004. "Privatizing Risk Without Privatizing the Welfare State: The Hidden Politics of Social Policy Retrenchment in the United States." American Political Science Review 98, no. 2: 243-60. doi: 10.1017/S00030554040 01121.

Hall, Peter A. 2016. "Politics as a Process Structured in Space and Time." In Orfeo Fioretos, Tulia G. Falleti, and Adam Sheingate, eds., The Oxford Handbook of Historical Institutionalism. Oxford, UK: Oxford University Press.

Halliday, Terrence C., and Gregory Shaffer. 2015. Transnational Legal Orders. New York, N.Y.: Cambridge University Press.

Hooghe, Liesbet, Gary Marks, Arjan H. Schakel, Sara Niedzwiecki, Sandra Chapman Osterkatz, and Sharon Shair-Rosenfield. 2016. Measuring Regional Au- 
thority: A Postfunctionalist Theory of Governance, Vol. 1. Oxford, UK: Oxford University Press.

Ingram, Matthew C. 2016. "Mandates, Geography, and Networks: Diffusion of Criminal Procedure Reform in Mexico." Latin American Politics and Society 58, no. 1: 121-45. doi: 10.1111/j.1548-2456.2016.00301.x.

Jacoby, Wade. 2002. "Ordering from the Menu." Paper presented at the Enlargement and European Governance ECPR Joint Session Workshops, Turin, Italy, March 22-27.

Jupille, Joseph, and James A. Caporaso. 2009. "Domesticating Discourses: European Law, English Judges, and Political Institutions." European Political Science Review 1, no. 2: 205-28. doi: 10.1017/S1755773909000149.

Kelemen, R. Daniel. 2011. Eurolegalism: The Transformation of Law and Regulation in the European Union. Cambridge, Mass.: Harvard University Press.

- 2016. "Constructing the European Judiciary." Paper presented at the 23rd International Conference for Europeanists, Philadelphia, Pa., April 16.

Kelemen, R. Daniel, and Tommaso Pavone. 2016. "Mapping European Law.” Journal of European Public Policy 23, no. 8: 1118-38. doi: 10.1080/13501763.2016 .1186211 .

—. 2018a. "Replication data for: The Political Geography of Legal Integration: Visualizing Institutional Change in the European Union." Harvard Dataverse, V1. At https://doi.org/10.7910/DVN/NTR9MZ.

— . 2018b. Supplementary material for "The Political Geography of Legal Integration: Visualizing Institutional Change in the European Union." At https://doi.org/10 .1017/S0043887118000011.

Krugman, Paul. 1991. "Increasing Returns and Economic Geography.” Journal of Political Economy 99, no. 3: 483-99. doi: 10.1086/261763.

Lindseth, Peter L. 2010. Power and Legitimacy: Reconciling Europe and the Nation State. Oxford, UK: Oxford University Press.

Mahoney, James, and Dietrich Rueschemeyer, eds. 2003. Comparative Historical Analysis in the Social Sciences. New York, N.Y.: Cambridge University Press.

Mahoney, James, and Kathleen Thelen. 2010. "A Theory of Gradual Institutional Change." In James Mahoney and Kathleen Thelen, eds., Explaining Institutional Change: Ambiguity, Agency, and Power. New York, N.Y.: Cambridge University Press.

Mann, Michael. 1984. "The Autonomous Power of the State: Its Origins, Mechanisms, and Results.” European Journal of Sociology 25, no. 2: 185-213. doi: 10.1017/S0003975600004239.

Martinsen, Dorte Sindbjerg. 2015. An Ever More Powerful Court? The Political Constraints of Legal Integration in the European Union. Oxford, UK: Oxford University Press.

Obermaier, Andreas. 2008. "The National Judiciary-Swords of the European Court of Justice: Rulings: The Example of the Kobll/Dekker Jurisprudence." European Law Journal 14, no. 6: 735-52.

Orren, Karen, and Stephen Skowronek. 2004. The Search for American Political Development. New York, N.Y.: Cambridge University Press.

Parsons, Craig. 2003. A Certain Idea of Europe. Ithaca, N.Y.: Cornell University Press.

Pavone, Tommaso. 2015. "Law Deserts and Legal Battlefields." Paper presented at the 2nd Annual University of Texas Graduate Conference in Public Law, Austin, Tex., September 24-26. 
Pech, Laurent, and Kim Lane Scheppele. 2017. "Illiberalism Within: Rule of Law Backsliding in the EU." Cambridge Yearbook of European Legal Studies 19, December: 3-47. doi: 10.1017/cel.2017.9.

Pierson, Paul. 1995. Dismantling the Welfare State? Reagan, Thatcher and the Politics of Retrenchment. New York, N.Y.: Cambridge University Press.

Plötner, Jens. 1998. "Report on France." In Anne-Marie Slaughter, Alec Stone Sweet, and Joseph H. H. Weiler, eds., The European Courts and National Courts Doctrine E' Jurisprudence: Legal Change in its Social Context. Oxford, UK: Hart Publishing.

Powell, Walter, and Paul DiMaggio, eds. 2012. The Nerw Institutionalism in Organizational Analysis. Chicago, Ill.: University of Chicago Press.

Robertson, Paul, and Richard Langlois. 1995. "Innovation, Networks, and Vertical Integration.” Research Policy 24, no. 4: 543-62. doi: 10.1016/S0048-7333 (94)00786-1.

Schimmelfennig, Frank, and Ulrich Sedelmeier. 2005. The Europeanization of Central and Eastern Europe. Ithaca, N.Y.: Cornell University Press.

Schultz, Kenneth A. 2015. "Mapping Interstate Territorial Conflict: A New Data Set and Applications." Journal of Conflict Resolution 61, no. 7: 1565-90. doi: 10.1177/0022002715620470.

Scott, James C. 1998. Seeing Like a State: How Certain Schemes to Improve the Human Condition Have Failed. New Haven, Conn.: Yale University Press.

Skowronek, Stephen. 1982. Building a Nerw American State: The Expansion of National Administrative Capacities, 1877-1920. Cambridge, UK: Cambridge University Press.

Soifer, Hillel. 2012. "Measuring State Capacity in Contemporary Latin America." Revista de Ciencia Politica 32, no. 3: 585-98.

. Forthcoming. "Choosing the Unit of Analysis in Subnational Comparison.” In Augustina Giraudy, Eduardo Moncada, and Richard Snyder, eds., Inside Countries: Subnational Research in Comparative Politics. New York, N.Y.: Cambridge University Press.

Stasavage, David. 2010. "When Distance Mattered: Georgraphic Scale and the Development of European Representative Assemblies." American Political Science Review 104, no. 4: 625-43. doi: 10.1017/S0003055410000444.

Staszak, Sarah. 2014. No Day in Court: Access to Justice and the Politics of Judicial Retrenchment. New York, N.Y.: Oxford University Press.

Stepan, Alfred C. 1999. "Federalism and Democracy: Beyond the US Model." Journal of Democracy 10 no. 4: 19-34. doi:10.1353/jod.1999.0072.

Stone Sweet, Alec. 2000. Governing with Judges: Constitutional Politics in Europe. New York, N.Y.: Oxford University Press.

- 2004. The Judicial Construction of Europe. New York, N.Y.: Oxford University Press.

- 2010. "The European Court of Justice and the Judicialization of EU Governance." Living Reviews in European Governance 5 no. 2: 1-50. doi: 10.12 942/lreg-2010-2.

Stone Sweet, Alec, and Thomas L. Brunell. 1998. “Constructing a Supranational Constitution: Dispute Resolution and Governance in the European Community." American Political Science Review 93, no. 1: 63-81. doi: 10.2307/2585929.

Strang, David, and John W. Meyer. 1993. "Institutional Conditions for Diffusion." Theory and Society 22, no. 4: 487-511. doi: 10.1007/BF00993595. 
Strang, David, and Sarah A. Soule. 1998. "Diffusion in Organizations and Social Movements: From Hybrid Corn to Poison Pills." Annual Review of Sociology 24, August: 265-90. doi: 10.1146/annurev.soc.24.1.265.

Strayer, Joseph. 1970. On the Medieval Origins of the Modern State. Princeton, N.J.: Princeton University Press.

Streeck, Wolfgang, and Kathleen Thelen. 2005. Beyond Continuity: Institutional Change in Advanced Political Economies. New York, N.Y.: Oxford University Press.

Teece, David J. 1996. "Firm Organization, Industrial Structure, and Technological Innovation." Journal of Economic Behavior E Organization 31, no. 2: 193224. doi: 10.1016/S0167-2681(96)00895-5.

Treib, Oliver. 2008. "Implementing and Complying with EU Governance Outputs." Living Reviews in European Governance 3, no. 5: 4-30. At http://edoc.vi fapol.de/opus/volltexte/2011/2474/pdf/lreg_2008_5Color.pdf, accessed April 12, 2018.

Treisman, Daniel. 2002. "Defining and Measuring Decentralization: A Global Perspective.” Working Paper. University of California, Los Angeles. At https:// www.sscnet.ucla.edu/polisci/faculty/treisman/Papers/defin.pdf., accessed April 12, 2018.

Tridimas, George, and Takis Tridimas. 2004. "National Courts and the European Court of Justice: A Public Choice Analysis of the Preliminary Reference Procedure." International Review of Law and Economics 24, no. 2: 125-45. doi: 10.1016/j.irle.2004.08.003.

Vallbe, Joan-Joseph. 2014. "Measuring the Judicial Power of Regions: A Judicial Regional Authority Index.” Working Paper. University of Barcelona. At https:// ecpr.eu/filestore/paperproposal/8bab9f0e-3ba5-4b0a-895a-b569e2ae8fb6 .pdf, accessed April 12, 2018.

Vauchez, Antoine, and Bruno de Witte, eds. 2013. Lawyering Europe: European Law as a Transnational Social Field. Oxford, UK: Hart Publishing.

Vink, Maarten, Monica Claes, and Christine Arnold. 2009. "Explaining the Use of Preliminary References by Domestic Courts in EU Member States." Paper presented at the 2009 European Union Studies Association Conference, Marina del Rey, April 24.

Weber, Max. 1921. "Politik als Beruf." In Gesammelte Politische Schriften. Munich, Germany: Duncker \& Humblodt. At http://polisci2.ucsd.edu/foundation/doc uments/03Weber1918.pdf, accessed April 13, 2018.

Weiler, J. H. H. 1991. “The Transformation of Europe.” Yale Law Journal 100, no. 8: 2403-83. At http://www.jstor.org/stable/i232711, accessed April 12, 2018.

- 1994. "A Quiet Revolution: The European Court of Justice and its Interlocutors." Comparative Political Studies 26, no. 4: 510-34. doi: 10.1177/0010 414094026004006.

Wind, Marlene. 2010. "The Nordics, the EU and the Reluctance towards Supranational Judicial Review.” Journal of Common Market Studies 48, no. 4: 103963. doi: 10.1111/j.1468-5965.2010.02085.x.

Ziblatt, Daniel. 2007. Structuring the State: The Formation of Italy and Germany and the Puzzle of Federalism. Princeton, N.J.: Princeton University Press. 